\title{
Three-Dimensional Contaminant Plume Dynamics in the Vadose Zone: Simulation of the 241-T-106 Single-Shell Tank Leak at Hanford
}

\author{
J. L Smoot \\ B. Sagar
}

January1990

Prepared for the U.S. Department of Energy under Contract DE-AC06-76RLO 1830

Pacific Northwest Laboratory

Operated for the U.S. Department of Energy by Battelle Memorial Institute 


\section{DISCLAIMER}

This report was prepared as an account of work sponsored by an agency of the United States Government. Neither the United States Government nor any agency thereof, nor Battelle Memorial Institute, nor any of their employees, makes any warranty, expressed or implied, or assumes any legal liability or responsibilityfor the accuracy, completeness, or usefulness of any information, apparatus, product, or process disclosed, or represents that its use would not infringe privately owned rights. Reference herein to any specific commercial product, process, or service by trade name, trademark, manufacturer, or otherwise, does not necessarily constitute or imply its endorsement, recommendation, or favoring by the United States Government of any agency thereof, or Battelle Memorial Institute. The views and opinions of authors expressed herein do not necessarily state or reflect those of the United States Government or any agency thereof.

\section{PACIFIC NORTHWEST LABORATORY operatedby \\ BATTELLE MEMORIAL INSTITUTE for the \\ UNITED STATES DEPARTMENT OF ENERGY under Contract DE-AC06-76RLO 1830}

Printed in the United States of America

Available to DOE and DOE contractors from the

Office of Scientific and Technical Information, P.O. Box 62, Oak Ridge, TN 37831; prices available from (615) 576-8401. FTS 626-8401.

Available to the public from the National Technical Information Service, U.S. Department of Commerce, 5285 Port Royal Rd., Springfield, VA 22161.

NTIS Price Codes, Microfiche A01

Printed Copy

\begin{tabular}{cr}
\hline Price Code & Page Range \\
\hline A02 & $1-10$ \\
A03 & $11-50$ \\
A04 & $51-75$ \\
A05 & $76-100$ \\
A06 & $101-125$ \\
A07 & $126-150$ \\
A08 & $151-175$ \\
A09 & $176-200$ \\
A10 & $201-225$ \\
A11 & $226-250$ \\
A12 & $251-275$ \\
A13 & $276-300$ \\
A14 & $301-325$
\end{tabular}

\begin{tabular}{cc}
\hline Price Code & Page Range \\
\hline A15 & $326-350$ \\
A16 & $351-375$ \\
A17 & $376-400$ \\
A18 & $401-425$ \\
A19 & $426-450$ \\
A20 & $451-475$ \\
A21 & $476-500$ \\
A22 & $501-525$ \\
A23 & $526-550$ \\
A24 & $551-575$ \\
A25 & $576-600$ \\
A99 & $601-U p$
\end{tabular}


PNL-7221

UC-702

THREE-DIMENSIONAL CONTAMINANT PLUME DYNAMICS IN THE VADOSE ZONE:

SIMULATION OF THE 241-T-106

SINGLE-SHELL TANK LEAK AT HANFORD

J. L. Smoot

B. Sagar

January 1990

Prepared for

the U.S. Department of Energy

under Contract DE-AC06-76RLO 1830

Pacific Northwest Laboratory

Richland, Washington 99352 
$-$

\section{•}




\section{$\underline{\text { SUMMARY }}$}

Approximately 2,000 $\mathrm{m}^{3}$ (115,000 gallons) of 1 iquid containing radioactive and chemical wastes leaked from the 241-T-106 single-shell tank at the U.S. Department of Energy's Hanford Site in southcentral Washington in 1973. The leak discharged into the unsaturated, coarse-grained sediments of the Hanford formation which underlie the base of the tank. The extent of the contaminant plume in the vadose zone was estimated in 1973 and 1978 by gamma spectrometry in dry wells drilled to monitor the leak. The leak provides an excellent opportunity to test the applicability of the PORFLO-3 Version 1.0 computer code for studying flow and transport in the vadose zone.

The PORFLO-3 computer code was used to study plume migration for 106Ru and $137 \mathrm{Cs}$. The flow and transport properties of the soils through which the plume has migrated are critical input data for the model but are not available. Consequently, information from a catalogue of Hanford Site soil properties was used. The transient magnitudes and locations of the plume were simulated in three dimensions.

Using viscosities and hydraulic conductivities for the tank fluid that are equal to that of water, the plume of $106 \mathrm{Ru}$ simulated for 1973 was larger than that which was measured. By reducing the hydraulic conductivity for saturated conditions in the vertical direction by one-half, the dimensions of the simulated 106Ru plume approximate those of the measured plume. Such reduction is justified because of the uncertainty inherent in the hydraulic conductivity data and because the tank fluid is more viscous than water. The plume of 137 Cs simulated for 1973 approximates that which was measured, assuming a reasonable distribution coefficient to account for the sorption of cesium by minerals of the Hanford formation.

Using the reduced vertical hydraulic conductivity, the migration of $106 \mathrm{Ru}$ and $137 \mathrm{Cs}$ was simulated for the time between 1973 and 1990. (The gamma spectrometry measurement in 1978 suggests that the 106Ru did not move after 1973.) The plume simulated for 1978 and 1990, however, does not show this behavior; it appears to have expanded significantly since 1973. Because 106Ru may have a small sorption coefficient, a simulation was made that 
assumed a distribution coefficient of 0.5 for ruthenium. Use of this coefficient, however, did not result in a stationary ${ }^{106} \mathrm{Ru}$ plume; the simulated plume continued to expand after 1973.

This value is reasonable based on information in the literature. However, the use of the distribution coefficient did not accurately reproduce the lateral spreading of the observed plume, and the simulated plume expanded significantly after 1973.

The simulated plume of cesium for 1978 and 1990 did not move significantly from that measured and simulated for 1973. This static condition likely resulted from the sorption of cesium by minerals of the Hanford formation.

Simulations of the 241-T-106 tank leak indicate that PORFLO-3 Version 1.0 should be able to represent the transient behavior of a threedimensional contaminant plume in the vadose zone. However, the quality of any simulation is directly proportional to the quality of the input data. The results of these simulations demonstrate the capability of the code; the results do not incorporate site-specific soil-moisture retention properties or site-specific radionuclide transport properties. These parameters should be measured. In addition, the 1989 distribution of the 106Ru and 137Cs plumes is unknown and should be measured. More data are needed for a comprehensive performance assessment analysis of the 241-T-106 tank leak. The results of this study indicate that such a performance assessment should be possible when site-specific data become available. 


\section{ACNOMEDGMENTS}

The authors would like to thank Dr. Jerry Davis and Mr. Mike Connelly of Westinghouse Hanford Company (MHC) for technical support during the project. The authors would also like to thank WHC for computational support on the Hanford Cray X-MP/18. 



\section{CONTENTS}

SLMAAY . . . . . . . . . . . . . . . . $i i i$

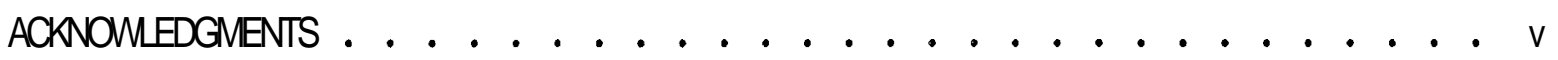

1.0 INTRODUCTION . . . . . . . . . . . . . . . . . . . . . . . . 1.1

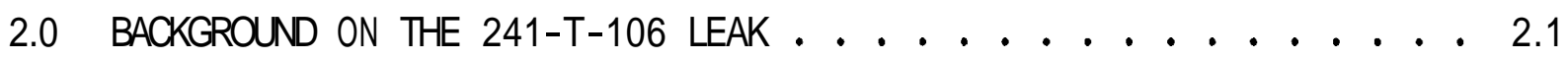

3.0 HMDROGEOLOGY . . . . . . . . . . . . . . . . . . . . . . . . . . 3.1

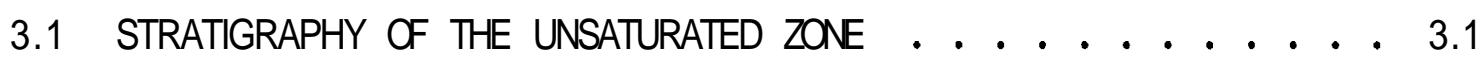

3.2 UNCONFINEDAQUIFER $\ldots \ldots \ldots \ldots \ldots$

3.3 WATRR MOVEVENT THROUGH THE UNSATURATED ZONE . . . . . . . . 3.4

3.3.1 Deep Percolation . . . . . . . . . . . . . . . . . 3.4

3.3.2 Moisture Retention Characteristics of the Vadose Zone Sediments ....................... 3.5

4.0 DESCRIPTION OF THE 241-T-106 SINGLE-SHELL TANK LEAK . . . . . . 4.1

5.0 NUMERICAL SIMULATION . . . . . . . . . . . . . . . . 5.1

5.1 CONCEPTUAL MODEL $\ldots \ldots \ldots \ldots \ldots \ldots . \ldots \ldots$

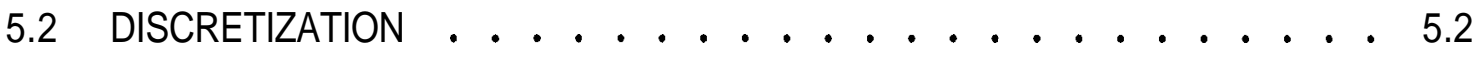

5.3 BOUNDARY AND INITIAL CONDITIONS . . . . . . . . . . 5.2

5.4 SOIL HYDRAULIC AND TRANSPORT PROPERTIES . . . . . . . . . . 5.4

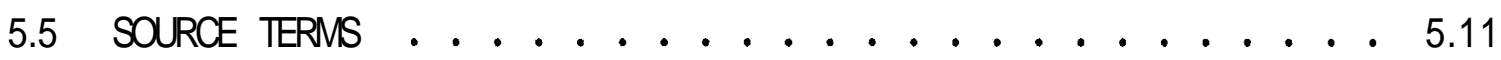

6.0 RESULTS OF SIMULATIONS . . . . . . . . . . . . . . . . . . . . 6.1

6.1 SOIL MOISTURE MOVEVENT $\ldots \ldots \ldots \ldots .1$

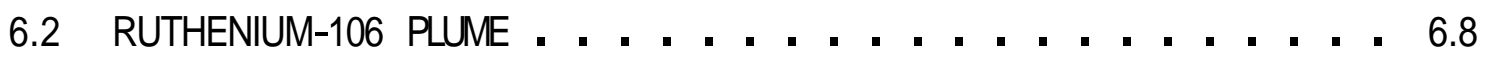

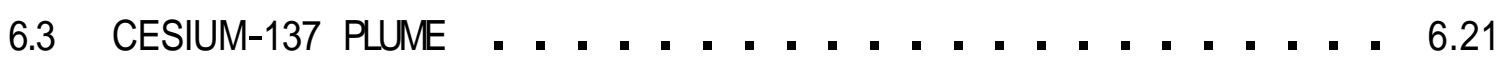

7.0 CONCLUSIONS $\ldots \ldots \ldots \ldots \ldots \ldots \ldots \ldots \ldots$

8.0 REFERENCES . . . . . . . . . . . . . . . . . . . 8.1 


\section{FIGURES}

2.1 Location of Hanford T Tank Farm . . . . . . . . . . . 2.2

2.2 Design of the 241-T-106 Single-Shell Tank . . . . . . . . 2.3

2.3 Placement of the 241-T-106 Single-Shell Tank . . . . . . 2.4

3.1 Stratigraphy of the T Tank Farm . . . . . . . . 3.2

3.2 Textures and Thicknesses of the Five Major Stratigraphic Zones at the T Tank Farm ................... 3.4

4.1 Plan and Vertical Cross-Sectional Views of the 137 Cs, $137 \mathrm{Ce}$,

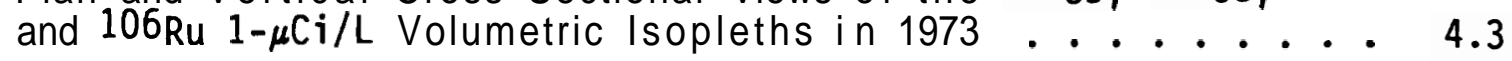

4.2 Vertical Cross Section of the 106Ru Plume . . . . . . . 4.4

4.3 Plan and Vertical Cross-Sectional Views of the $137 \mathrm{Cs}, 137 \mathrm{Ce}$, and 106Ru $1-\mu \mathrm{Ci} / \mathrm{L}$ Volumetric Isopleths in $1978 \ldots \ldots . . . . .4$

5.1 Discretization of the Three-Dimensional Model ....... 5.3

5.2 Boundary Conditions of the Three-Dimensional Model . . . . 5.4

5.3 Moisture Retention Curves Identified for Stratigraphic Units One and Five at the T Tank Farm ................

5.4 Moisture Retention Curves1 Identified for Stratigraphic Unit Two at the T Tank Farm .............. 5.8

5.5 Moisture Retention Curves Identified for Stratigraphic Unit Three at the T Tank Farm ..................

5.6 Moisture Retention Curves Identified for Stratigraphic Unit Four at the T Tank Farm ..................

5.7 Hydraulic Coefficients for the Five Stratigraphic Units Identified at the T Tank Farm . . . . . . . . . 5.11

6.1 PORFLO-3 Simulation of Relative Saturation at 150 Days . . . 6.2

6.2 PORFLO-3 Simulation of Relative Saturation at 365 Days . . . 6.3

6.3 PORFLO-3 Simulation of Relative Saturation at 2,555 Days . . . 6.4

6.4 PORFLO-3 Simulation of Relative Saturation at 4,015 Days . . . 6.5

6.5 PORFLO-3 Simulation of Relative Saturation at 5,475 Days . . 6.6

6.6 PORFLO-3 Simulation of Water Velocities at 100 Days $\quad . \quad . .6 .7$ 
6.7 PORFLO-3 Simulation of the Vertical Extent of the 106Ru $1-\mu \mathrm{Ci} / \mathrm{L}$ Isopleth Using Data from Field Measurements ........

6.8 PORFLO-3 Simulation of the Horizontal Extent of the 106Ru $1-\mu \mathrm{Ci} / \mathrm{L}$ Isopleth Using Data from Field Measurements . . . . . . 6.10

6.9 PORFLO-3 Simulation of the Vertical Extent of the $106 \mathrm{Ru} 1-\mu \mathrm{Ci} / \mathrm{L}$ Isopleth With Adjusted Vertical Hydraulic Conductivity at Early

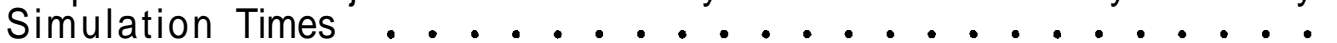

6.10 PORFLO-3 Simulation of the Vertical Extent of 106Ru After 100 Days With Adjusted Vertical Hydraulic Conductivity .........

6.11 PORFLO-3 Simulation of the Horizontal Extent of the 106Ru 1- $\mu \mathrm{Ci} / \mathrm{L}$ Isopleth With Adjusted Vertical Hydraulic Conductivity at Early Simulation Times.................

6.12 PORFLO-3 Simulation of the Vertical Extent of the $106 \mathrm{Ru} 1-\mu \mathrm{Ci} / \mathrm{L}$ Isopleth With Adjusted Vertical Hydraulic Conductivity at Late

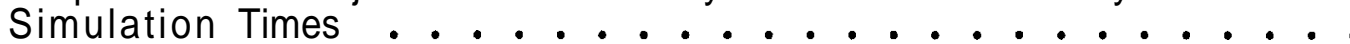

6.13 PORFLO-3 Simulation of the Horizontal Extent of the $106 \mathrm{Ru} 1-\mu \mathrm{Ci} / \mathrm{L}$ Isopleth With Adjusted Vertical Hydraulic Conductivity at Late

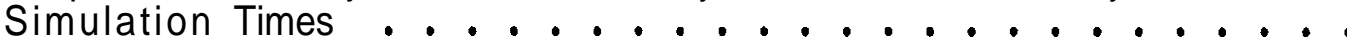

6.14 PORFLO-3 Simulation of the Vertical Extent of the $106 \mathrm{Ru} 1-\mu \mathrm{Ci} / \mathrm{L}$ Isopleth for Hydraulically Isotropic Stratigraphic Units With a Distribution Coefficient of $0.5 \mathrm{~mL} / \mathrm{g}$ at Early Simulation Times

6.15 PORFLO-3 Simulation of the Vertical Extent of the 106Ru $1-\mu \mathrm{Ci} / \mathrm{L}$ Isopleth for Hydraulically Isotropic Stratigraphic Units With a Distribution Coefficient of $0.5 \mathrm{~mL} / \mathrm{g}$ at Late Simulation Times . .

6.16 PORFLO-3 Simulation of the Horizontal Extent of the $106 \mathrm{Ru} 1-\mu \mathrm{Ci} / \mathrm{L}$ Isopleth for Hydraulically Isotropic Stratigraphic Units With a Distribution Coefficient of $0.5 \mathrm{~mL} / \mathrm{g} \ldots \ldots$

6.17 PORFLO-3 Simulation of the Vertical Extent of the $137 \mathrm{Cs} 1-\mu \mathrm{Ci} / \mathrm{L}$ Isopleth Using Data from Field Measurements .........

6.18 PORFLO-3 Simulation of the Horizontal Extent of the $137 \mathrm{Cs} 1-\mu \mathrm{Ci} / \mathrm{L}$ Isopleth Using Data from Field Measurements . . . . . . . . 


\section{TABLES}

2.1 Single-Shell Tank Assumed Leakers . . . . . . . . . . . . 2.5

4.1 Radionuclide Inventory of the 241-T-106 Tank Supernatant

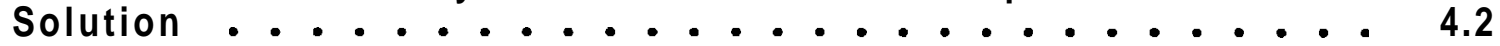

5.1 T Tank Farm Soil Properties and the Corresponding 241-AP Soi 1 Catalogue Properties Used in the Modeling Analysis . . . . 5.6 


\subsection{INTRODUCTION}

Chemical processing of spent nuclear fuel at the Hanford Site, located in southcentral Washington State, has resulted in the accumulation of large inventories of chemical, nuclear, and mixed wastes. From 1943 to 1964, a large part of this waste was stored underground in 149 single-she11 tanks. One of the biggest leaks of single-shell tanks was detected on June 8, 1973, in the 241-T-106 single-she11 tank located in the 200-West Area. Based on monitoring of liquid levels inside the tank, it was estimated that approximately 115,000 gallons of liquid were discharged to the soil (AEC-RL 1973; ARHCO 1973; Gillette 1973). Observation holes were drilled around the leak site to delineate the plume. Concentrations of radionuclide species were estimated from total gamma energy in the observation holes (ARHCO 1973). Measurements were made in 1973 and 1978 (Routson et al. 1979). In the present study, staff at the Pacific Northwest Laboratory, (a) in work funded by the U.S. Department of Energy (DOE) in support of Westinghouse Hanford Company, used field data to calibrate a complex numerical model of the T-106 site and then used the calibrated model to predict the present extent of the pl ume.

The computer code used in this study to model the 241-T-106 leak was PORFLO-3 Version 1.0 (Runchal and Sagar 1989; Sagar and Runchal 1989). PORFLO-3 is one of the hydrologic flow and transport computer codes that will be used to develop mathematical models from data collected at the Hanford Site and other DOE sites in order to evaluate the effectiveness of proposed remediation measures and the effects of new waste disposal activities. PORFLO-3 was designed to analyze flow and transport in complex, variably saturated, three-dimensional hydrogeologic settings. The 241-T-106 singleshell tank leak provides an opportunity to test the PORFLO-3 code; the ability to develop a model that approximates the extent of a measured plume engenders confidence in both the code and the data.

To obtain useful results, a large amount of data related to the leak and the site-specific hydrogeology is needed. Chapters 2, 3, and 4 discuss the

(a) The Pacific Northwest Laboratory is operated for the U.S. Department of Energy by Battelle Memorial Institute under Contract DE-AC06-76RLO 1830. 
leak's history, the hydrogeology of the area in which the tank is located, and the nature of the leak. The conditions assumed in the model and the results of the model are discussed in Chapters 5 and 6 . Chapter 7 summarizes the results and contains suggestions for future data collection. 


\subsection{BACKGROUND ON THE 241-T-106 LEAK}

A total of 149 single-shell tanks are buried in the 200-East and 200West Areas at Hanford (Figure 2.1). Sixty-six are located in the 200-East Area and 83 in the 200-West Area. The tanks are called single-shell tanks because they are constructed of concrete with a single-shell layer of carbonsteel lining. In contrast, tanks of more recent construction have two carbon-steel linings and are called double-she1l tanks. The tanks are generally configured into "tank farms," which consist of groups of 6 to 18 buried tanks connected by pipes. Tank farms generally receive waste via pipe lines.

The wastes of a given tank farm were originally a product of the specific facilities and production processes being serviced by each tank farm. Both radioactive and chemical wastes were pumped into the tanks. In the early 1970s, the pumpable liquid wastes were pumped out and reprocessed to remove $90 \mathrm{Sr}$ and $137 \mathrm{Cs}$ that were generating high heat loads within the tanks. The wastes were then returned to the tanks with some mixing and likely misrouting during the process.

Single-shell tanks have dimensions ranging from 6 to $23 \mathrm{~m}$ (15 to $75 \mathrm{ft})$ in diameter and 6 to $15 \mathrm{~m}(15$ to $50 \mathrm{ft})$ in height; they consist of buried concrete shells that are lined with a single layer of high carbon steel (Figure 2.2). The tanks are buried 40 to $70 \mathrm{~m}$ above the water table and are typically covered by several meters of overburden. Spatial relationships for the various sizes of tanks in each tank farm are shown in Figure 2.3. The 241-T-106 tank is a type II tank, having a diameter of $23 \mathrm{~m}(75 \mathrm{ft})$, a height of $8.5 \mathrm{~m}(28 \mathrm{ft})$, and a storage capacity of $2,000 \mathrm{~m}^{3}(500,000 \mathrm{gal})$.

Thurman (1989) reported that 66 of the 149 single-shell tanks are assumed to have leaked, and Jensen et al. (1989) noted that the combined leak volume is about $2,800 \mathrm{~m}^{3}(750,000 \mathrm{gal})$. The leaking single-shell tanks are listed in Table 2.1. Almost every tank farm is represented in the list. It is apparent that single-shell tank leakage is not an isolated problem. A more comprehensive analysis at a scale larger than the single tank scale used in the present analysis may be required to assess the effects of the leaks. 


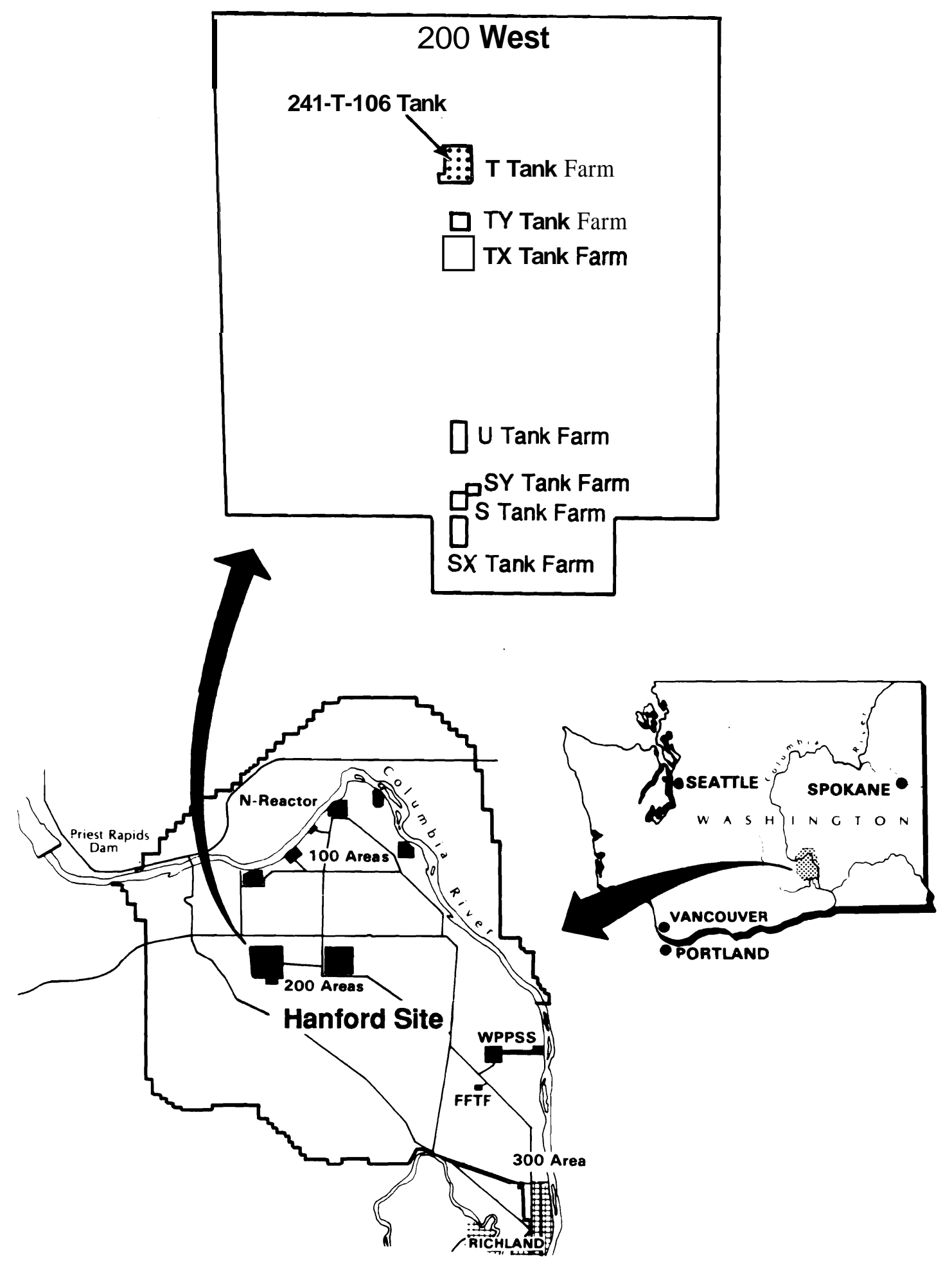

FIGURE 2.1. Location of Hanford T Tank Farm 


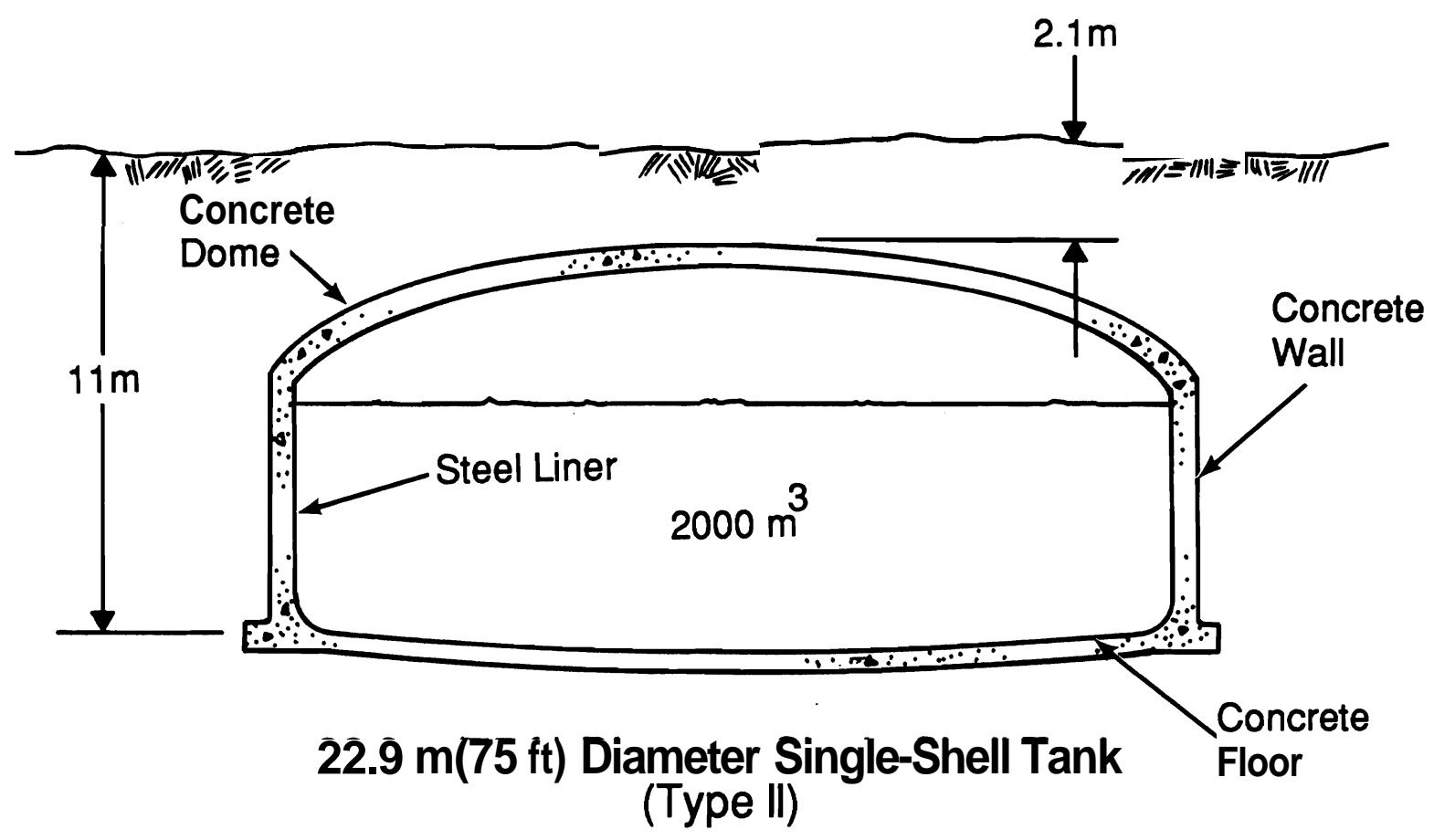

FIGURE 2.2. Design of the 241-T-106 Single-Shell Tank (after DOE 1987)

ARHCO (1973) and Routson et al. (1979) described the 241-T-106 tank leak in detail, and their work provides important information for this modeling analysis. 


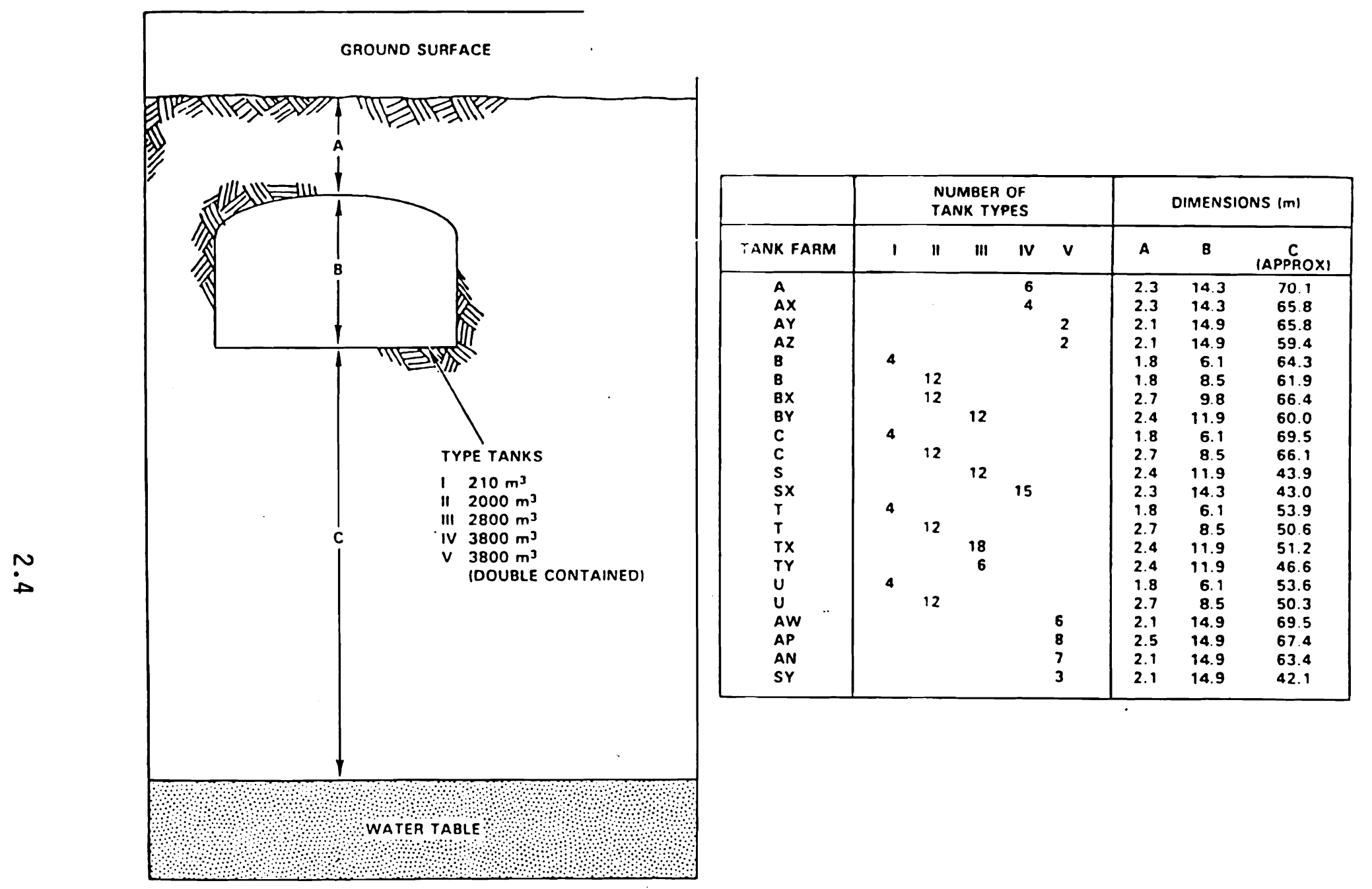

FIGUR Z 3 Placement of the Z41-T-106 Single-Shel Ifatr (Ifter DOE 1987) 
TABLE 2.1. Single-She11 Tank Assumed Leakers (after Thurman 1989)

\begin{tabular}{|c|c|c|c|}
\hline Tank Number & $\begin{array}{c}\text { Year of } \\
\text { Construction }\end{array}$ & $\begin{array}{l}\text { Year Removed(a) } \\
\text { From Service }\end{array}$ & $\begin{array}{r}\text { Operating } \\
\text { Capacity, g }\end{array}$ \\
\hline \multicolumn{4}{|c|}{ 200-EAST AREA: 32 Tanks } \\
\hline \multicolumn{4}{|c|}{ Waste Management Area B-BX-BY } \\
\hline $\begin{array}{l}241-B-101 \\
241-B-103 \\
241-B-105 \\
241-B-107 \\
241-B-110 \\
241-B-111 \\
241-B-112 \\
241-B-201 \\
241-B-203 \\
241-B-204\end{array}$ & $\begin{array}{l}1943-1944 \\
1943-1944 \\
1943-1944 \\
1943-1944 \\
1943-1944 \\
1943-1944 \\
1943-1944 \\
1943-1944 \\
1943-1944 \\
1943-1944\end{array}$ & $\begin{array}{l}1974 \\
1977 \\
1972 \\
1969 \\
1971 \\
1976 \\
1977 \\
1971 \\
1977 \\
1977\end{array}$ & $\begin{array}{r}500,000 \\
500,000 \\
500,000 \\
500,000 \\
500,000 \\
500,000 \\
500,000 \\
55,000 \\
55,000 \\
55,000\end{array}$ \\
\hline $\begin{array}{l}241-B X-101 \\
241-B X-102 \\
241-B X-108 \\
241-B X-110 \\
241-B X-111\end{array}$ & $\begin{array}{l}1946-1947 \\
1946-1947 \\
1946-1947 \\
1946-1947 \\
1946-1947\end{array}$ & $\begin{array}{l}1972 \\
1971 \\
1974 \\
1977 \\
1977\end{array}$ & $\begin{array}{l}500,000 \\
500,000 \\
500,000 \\
500,000 \\
500,000\end{array}$ \\
\hline $\begin{array}{l}241-\mathrm{BY}-103 \\
241-\mathrm{BY}-105 \\
241-\mathrm{BY}-106 \\
241-\mathrm{BY}-107 \\
241-\mathrm{BY}-108\end{array}$ & $\begin{array}{l}1948-1949 \\
1948-1949 \\
1948-1949 \\
1948-1949 \\
1948-1949\end{array}$ & $\begin{array}{l}1973 \\
1974 \\
1977 \\
1974 \\
1972\end{array}$ & $\begin{array}{l}750,000 \\
750,000 \\
750,000 \\
750,000 \\
750,000\end{array}$ \\
\hline
\end{tabular}

Waste Management Area C

$\begin{array}{rrrr}241-C-101 & 1943-1944 & 1970 & 500,000 \\ 241-C-110 & 1943-1944 & 1976 & 500,000 \\ 241-C-111 & 1943-1944 & 1978 & 500,000 \\ 241-C-201 & 1943-1944 & 1977 & 55,000 \\ 241-C-202 & 1943-1944 & 1977 & 55,000 \\ 241-C-203 & 1943-1944 & 1977 & 55,000 \\ 241-C-204 & 1943-1944 & 1977 & 55,000\end{array}$

Waste Management Area A-AX

$\begin{array}{llll}241-A-103 & 1954-1955 & 1980 & 1,000,000 \\ 241-A-104 & 1954-1955 & 1975 & 1,000,000 \\ 241-A-105 & 1954-1955 & 1963 & 1,000,000 \\ & & & \\ 241-A X-102 & 1963-1964 & 1980 & 1,000,000 \\ 241-A X-104 & 1963-1964 & 1978 & 1,000,000\end{array}$

(a) The last year the tank was capable of receiving waste; actual date of last waste receipt may have been earlier. 
TABLE 2.1. (contd)

$\begin{array}{llll}\text { Tank Number } & \begin{array}{c}\text { Year of } \\ \text { Construction }\end{array} & \begin{array}{c}\text { Year Removed(a) } \\ \text { From Service }\end{array} & \begin{array}{c}\text { Operating } \\ \text { Capacity, gal }\end{array} \\ & & \end{array}$

Waste Management Area T

$\begin{array}{llll}241-T-103 & 1943-1944 & 1974 & 500,000 \\ 241-T-106 & 1943-1944 & 1973 & 500,000 \\ 241-T-107 & 1943-1944 & 1976 & 500,000 \\ 241-T-108 & 1943-1944 & 1974 & 500,000 \\ 241-T-109 & 1943-1944 & 1974 & 500,000 \\ 241-T-111 & 1943-1944 & 1974 & 500,000 \\ 241-T X-105 & 1947-1948 & 1977 & 750,000 \\ 241-T X-107 & 1947-1948 & 1977 & 750,000 \\ 241-T X-110 & 1947-1948 & 1977 & 750,000 \\ 241-T X-113 & 1947-1948 & 1971 & 750,000 \\ 241-T X-114 & 1947-1948 & 1971 & 750,000 \\ 241-T X-115 & 1947-1948 & 1977 & 750,000 \\ 241-T X-116 & 1947-1948 & 1969 & 750,000 \\ 241-T X-117 & 1947-1948 & 1969 & 750,000 \\ 241-T Y-101 & 1951-1952 & 1973 & 750,000 \\ 241-T Y-103 & 1951-1952 & 1973 & 750,000 \\ 241-T Y-104 & 1951-1952 & 1974 & 750,000 \\ 241-T Y-105 & 1951-1952 & 1980 & 750,000 \\ 241-T Y-106 & 1951-1952 & 1959 & \end{array}$

Waste Manaqement Area U

$\begin{array}{llll}241-U-101 & 1943-1944 & 1960 & 500,000 \\ 241-U-104 & 1943-1944 & 1951 & 500,000 \\ 241-U-110 & 1943-1944 & 1975 & 500,000 \\ 241-U-112 & 1943-1944 & 1970 & 500,000\end{array}$

Waste Manaaement Area S-SX

$\begin{array}{lllr}241-S-104 & 1950-1951 & 1968 & 750,000 \\ 241-S X-104 & 1953-1954 & 1980 & 1,000,000 \\ 241-S X-107 & 1953-1954 & 1964 & 1,000,000 \\ 241-S X-108 & 1953-1954 & 1962 & 1,000,000 \\ 241-S X-109 & 1953-1954 & 1965 & 1,000,000 \\ 241-S X-110 & 1953-1954 & 1976 & 1,000,000 \\ 241-S X-111 & 1953-1954 & 1974 & 1,000,000 \\ 241-S X-112 & 1953-1954 & 1969 & 1,000 \\ 241-S X-113 & 1953-1954 & 1958 & 1,000 \\ 241-S X-114 & 1953-1954 & 1972 & 1,000,000 \\ 241-S X-115 & 1953-1954 & 1965 & 1,000,000\end{array}$

(a) The last year the tank was capable of receiving waste; actual date of last waste receipt may have been earlier. 


\subsection{HYDROGEOLOGY}

The hydrogeology of the area of the 241-T-106 tank is described in terms of the stratigraphy of the area, the unconfined aquifer, and water movement (moisture retention and recharge) through the unsaturated zone.

\subsection{STRATIGRAPHY OF THE UNSATURATED ZONE}

The single-shell tanks are buried in generally coarse-grained sediments of Pleistocene and Holocene age that overlie the Columbia River basalts in the Pasco Basin. The sediments overlying the basalts are divided into the Ringold Formation and the overlying Hanford formation, separated by a distinct unit of Plio-Pleistocene age. The Ringold Formation is of Pliocene age, and is generally coarse-grained, but with occasional thin layers of fine sand or silt with small amounts of clay. Caliche is observed in both the basal Ringold and the Plio-Pleistocene unit. The Hanford formation is of Pleistocene age and consists of a very coarse-grained flood facies called.the Pasco Gravels and a finer-grained slackwater facies called the Touchet Beds.

Tal lman et al. (1979) , Bjornstad (1983), DOE (1987), and more recently Jensen et al. (1989), Last and Bjornstad (1989), and Last et al. (1989) describe the geology of the unconsolidated sediments in the vicinity of the 200-West Area. In general, the vadose zone consists of a portion of the thick, relatively coarse-grained, elastic sediments of the middle Ringold Formation, overlain by the finer-grained, elastic sediments of the upper Ringold Formation and the Plio-Pleistocene unit, overlain in turn by the coarser-grained sands and gravels of the Hanford formation, which are exposed at the surface. The upper 10 to $20 \mathrm{~m}$ of the Hanford formation were locally excavated and back-filled during installation of the single-she1l tanks. In the remainder of this report, this zone is described as backfill to distinguish it from undisturbed Hanford formation.

Price and Fecht (1976) and Fecht and Price (1977) focus on the geology of the 241-T Tank Farm. Their 1976 report provides the most detailed geologic interpretation of the hydraulic (hydrologic) properties around the T-106 tank (see Figure 3.1). The water table is located within a thick sequence of sandy gravel that probably is part of the middle member of the 

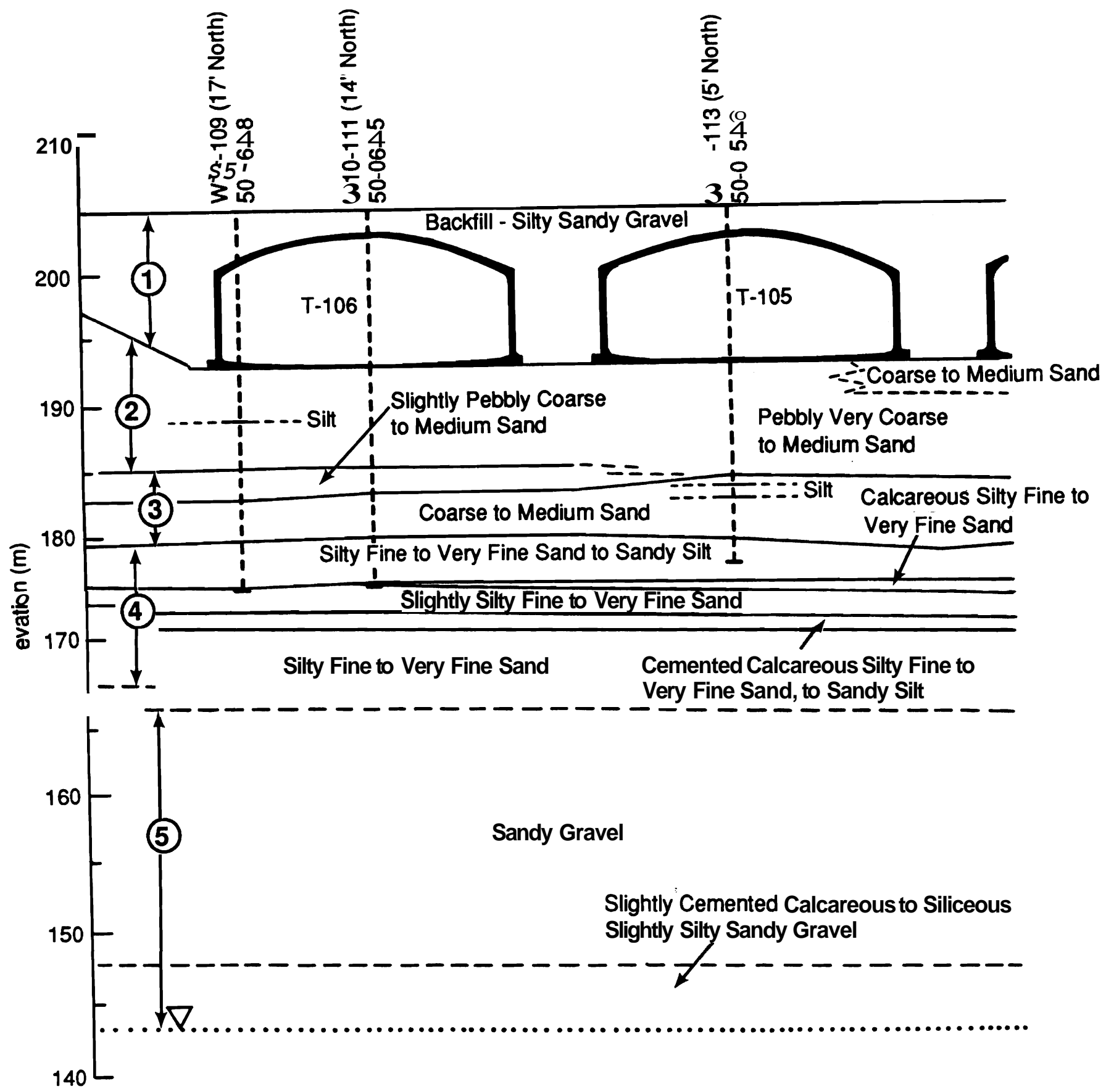

FIGURE 3.1. Stratigraphy of the T Tank Farm (after Price and Fecht 1976)

Ringold Formation. These coarse-grained sediments are overlain by about $14 \mathrm{~m}$ of fine-grained sediments that probably are part of the upper Ringold Formation and at least a portion of the $\mathrm{Pl}$ io-Pleistocene unit. These sediments consist of layered silty, fine to very-fine-grained sand with 
intercalated, calcareous zones. At an elevation of about $173 \mathrm{~m}$, or approximately $30 \mathrm{~m}$ below the surface, the sediments appear to be highly cemented by caliche.

Overlying the fine-grained sediments are about $4 \mathrm{~m}$ of somewhat coarsergrained material consisting of coarse to medium-grained sand with some pebbles in the upper portion. This zone may contain sediments from both the upper Plio-Pleistocene unit and the lower portion of the Hanford formation. Above this zone, about $8 \mathrm{~m}$ of the pebbly, very coarse to medium-grained sands of the Hanford formation extend to the base of the single-shell tanks. The backfil1, silty, sandy, gravel, composes the remaining $12 \mathrm{~m}$ of sediments to the surface. The backfill was derived from the excavated material.

Based primarily on the work of Price and Fecht (1976), but in general agreement with more recent work, five stratigraphic subdivisions may be inferred for the unsaturated zone in the vicinity of the 241-T Tank Farm. These zones are shown in Figure 3.2. The total section is $61 \mathrm{~m}$ thick. Beginning at the water table, the vadose zone consists of about $23 \mathrm{~m}$ of sandy gravel overlain by $14 \mathrm{~m}$ of calcareous, silty fine-grained to very fine sand, which may include a caliche layer. Above this is $4 \mathrm{~m}$ of coarse to mediumgrained sand overlain by $8 \mathrm{~m}$ of pebbly, very coarse to medium-grained sand, which in turn is overlain by $8 \mathrm{~m}$ of pebbly, very coarse to medium-grained sand, and finally capped by about $12 \mathrm{~m}$ of silty, sandy, gravelly backfill.

\subsection{UNCONEINED AQUIFER}

The unconfined aquifer in the vicinity of the 241-T-106 tank is contained within the unconsolidated sediments of the middle, lower, and basal members of the Ringold Formation; the underlying Columbia River basalts are assumed to form the base of this aquifer. Water levels in the unconfined aquifer are well documented for recent years. Ground water flows generally toward the Columbia River. Depths to water are commonly on the order of 60 to $80 \mathrm{~m}$.

There may be some hydraulic communication between confined aquifers in the basalt and the unconfined aquifer, although the direction and magnitude 


\section{T-106 Stratigraphy}

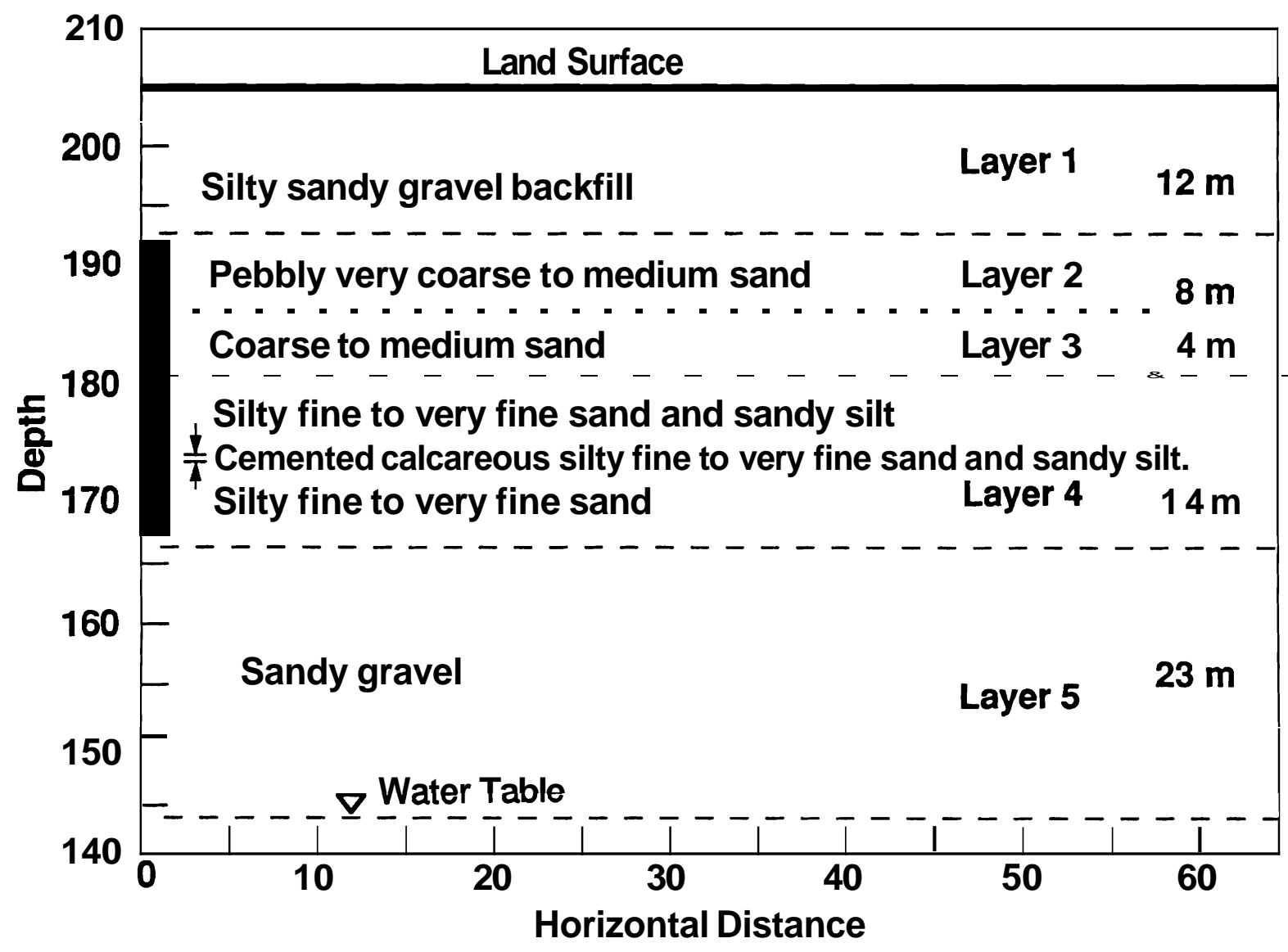

FIGURE 3.2. Textures and Thicknesses of the Five Major Stratigraphic Zones at the $\mathrm{T}$ Tank Farm

of any such flow are yet to be documented. Hydraulic conductivity and saturated thickness of the unconfined aquifer vary considerably across the site, yet produce a relatively constant distribution of transmissivity.

\subsection{WATER MOVEVENT THROLAH THE UNSATURATED ZONE}

\subsubsection{Deep Percolation (Recharge)}

Water from precipitation infiltrating past the root zone wil1 percolate downward through the unsaturated zone. This water constitutes recharge to the unconfined aquifer. The percentage of precipitation that becomes available for recharge is a subject of continued research at Hanford. Gee (1987) notes that recharge rates at the Hanford Site may vary from zero to more than the average annual precipitation at specific locations. He notes 
that measured differences in drainage in a wide variety of lysimeters installed at the Hanford Site may be attributable to differences in plant cover. Maximum drainage tends to occur in areas that have no plant cover, such as the bare, gravelled surface maintained at the T Tank Farm. H notes that at areas such as the tank farm sites, where the surface is gravelly, "most of the annual precipitation can be expected to drain through the gravel and be available for recharge." The average annual precipitation at the Hanford Site is about $15 \mathrm{~cm} / \mathrm{yr}$; consequently, the surface of the T Tank Farm may allow a significant portion of this water to become available for recharge.

The manner in which the tanks alter the flow field may also be an important factor with respect to recharge. The tanks can be expected to divert infiltrating water that encounters their domed tops. This water would then percolate along the sides of the tanks, producing a ring of soil beneath the tanks that may be of a relatively higher moisture content and, therefore, higher hydraulic conductivity. Philip et al. (1989) report similar phenomena for smaller-scale features in the unsaturated zone. However, measurements to support this hypothesis for the tank farms have not yet been made.

\subsubsection{Moisture Retention Characteristics of the Vadose Zone Sediments}

Moisture retention properties of soils and sediments are critical hydrologic parameters for analyzing water flow for unsaturated conditions but have not been measured for the soils at the 241-T Tank Farm. For the purposes of this analysis, soil moisture retention characteristics were estimated using a qualitative comparison of soil textural and stratigraphic properties with catalogues of data that document these characteristics for specific Hanford Site locations. Details of these characteristic curves are provided in Section 5.4. 



\subsection{DESCRIPTION OF THE 241-T-106 SINGLE-SHELL TANK LEAK}

Routson et al. (1979) provide a detailed chronology of the 241-T-106 tank leak. Leakage began on or about April 20, 1973, when the tank was filled with reprocessed wastes. Leakage stopped on June 10, 1973, when the pumpable liquid contents of the tank were removed. The total duration of the leak was approximately 52 days, during which 115,000 gallons of supernate were lost from the tank.

The radionuclide inventory of the supernate solution within the tank is shown in Table 4.1. Most of the inventory consists of $144 \mathrm{Ce} / 144 \mathrm{Pr}, 137 \mathrm{Cs}$, ${ }^{89} \mathrm{Sr} / 90 \mathrm{Sr}$, and $106 \mathrm{Ru} / 106 \mathrm{Rh}$, with lesser amounts of the other radionuclides. With the exception of $106 \mathrm{Ru} / 106 \mathrm{Rh}$, the inventory is characterized by long half-1ives and high sorption coefficients. The inventory in Table 4.1 corresponds to about $2.67 \times 10^{5} \mathrm{Ci}$ of $106 \mathrm{Ru}$ and $3.85 \times 10^{4} \mathrm{Ci}$ of $137 \mathrm{Cs}$. This compares to $4 \times 10^{4} \mathrm{Ci}$ of $137 \mathrm{Cs}$ reported by the U.S. Energy Research and Development Agency (1975). Ruthenium-106 has a half-life of about 1 year, and sorption coefficients are generally small. Consequently, the movement of ${ }_{106 R u}$ should be essentially concurrent with the fluid front.

The tank leak apparently occurred on the southeast side of the tank. The contaminant plume is centered around this portion of the tank. Figure 4.1 shows both a plan view and a vertical cross-sectional view of the plume in the summer of 1973, after the leak had been detected and the tank pumped out. Contaminant transport is shown for $106 \mathrm{Ru}, 144 \mathrm{Ce}$, and $137 \mathrm{Cs}$. Ruthenium-106 is the most mobile of the three and had traveled the farthest, while 137 Cs is the least mobile and was contained within a small zone around the base of the tank. The configuration of the 106Ru plume appears to be approximately circular, with a radius of about 15 to $20 \mathrm{~m}$ in plan view and a maximum depth of penetration of about $20 \mathrm{~m}$ Figure 4.2 shows the horizontal and vertical distribution of $106 \mathrm{Ru}$ for several isopleths. The figure reveals a relatively steep distribution front both laterally and vertically.

Figure 4.3 shows the isopleths measured for 106Ru $1-\mu \mathrm{Ci} / \mathrm{L}$ in 1973 and 1978. From Figure 4.3, the 106Ru $1-\mu \mathrm{Ci} / \mathrm{L}$ is opleth does not appear to have migrated during this period. Because of its relatively short (1-yr) halflife, the 106Ru would decay from the $2.7 \times 1011 \mu \mathrm{Ci}$ leaked from the tank in 
TABLE 4.1. Radionuclide Inventory of the 241-T-106 Tank

Supernatant Solution (after Routson et al. 1979)

Radioactive Component

Ceri um-144/Praseodymi um-144

Cesium-137

Europium-155

Cesi urn-134

Antimony -125

Strontium-89/Strontium-90

Rutheni um-106/Rhodium-106

Pl utoni urn-239

Pl utoni urn-240

Arnerici um-241
$\mathrm{Ci} / 1$

$1.18 \times 10^{4}$

$8.85 \times 10^{4}$

$1.69 \times 10^{3}$

$1.32 \times 10^{3}$

$1.12 \times 10^{4}$

$2.98 \times 10^{4}$

$6.12 \times 10^{5}$

9

2

2
$\mathrm{Ci} / \mathrm{gal}$

$4.48 \times 10^{4}$

$3.35 \times 10^{5}$

$6.40 \times 10^{3}$

$5.00 \times 10^{3}$

$4.24 \times 10^{3}$

$1.13 \times 10^{5}$

$2.32 \times 10^{6}$

34

8

6 

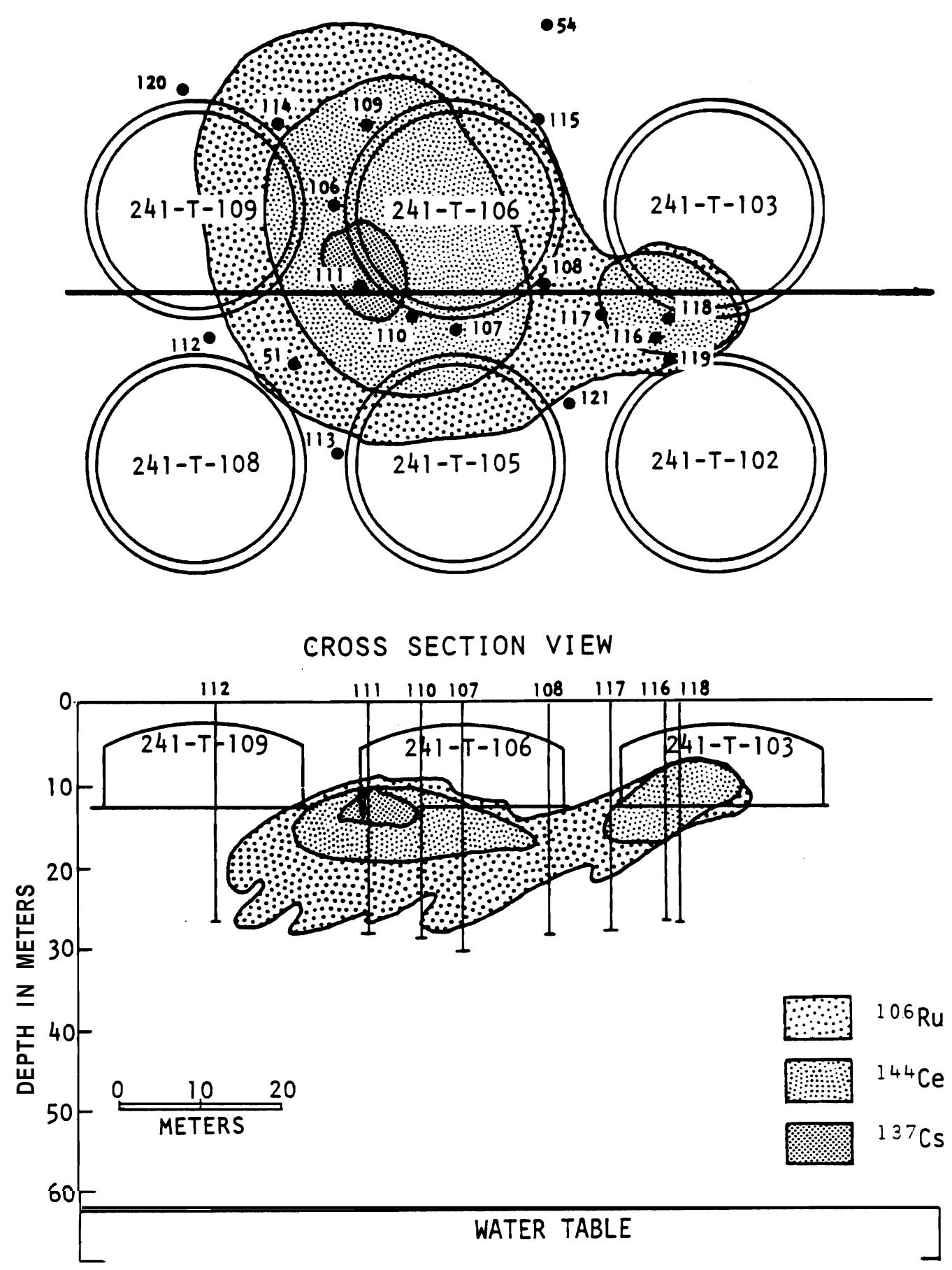

FIGURE 4.1. Plan and Vertical Cross-Sectional Views of the $137 \mathrm{Cs}$, $137 \mathrm{Ce}$, and 106Ru 1- $\mu \mathrm{Ci} / \mathrm{L}$ Volumetric Isopleths in 1973 (after Routson et a1. 1979) 

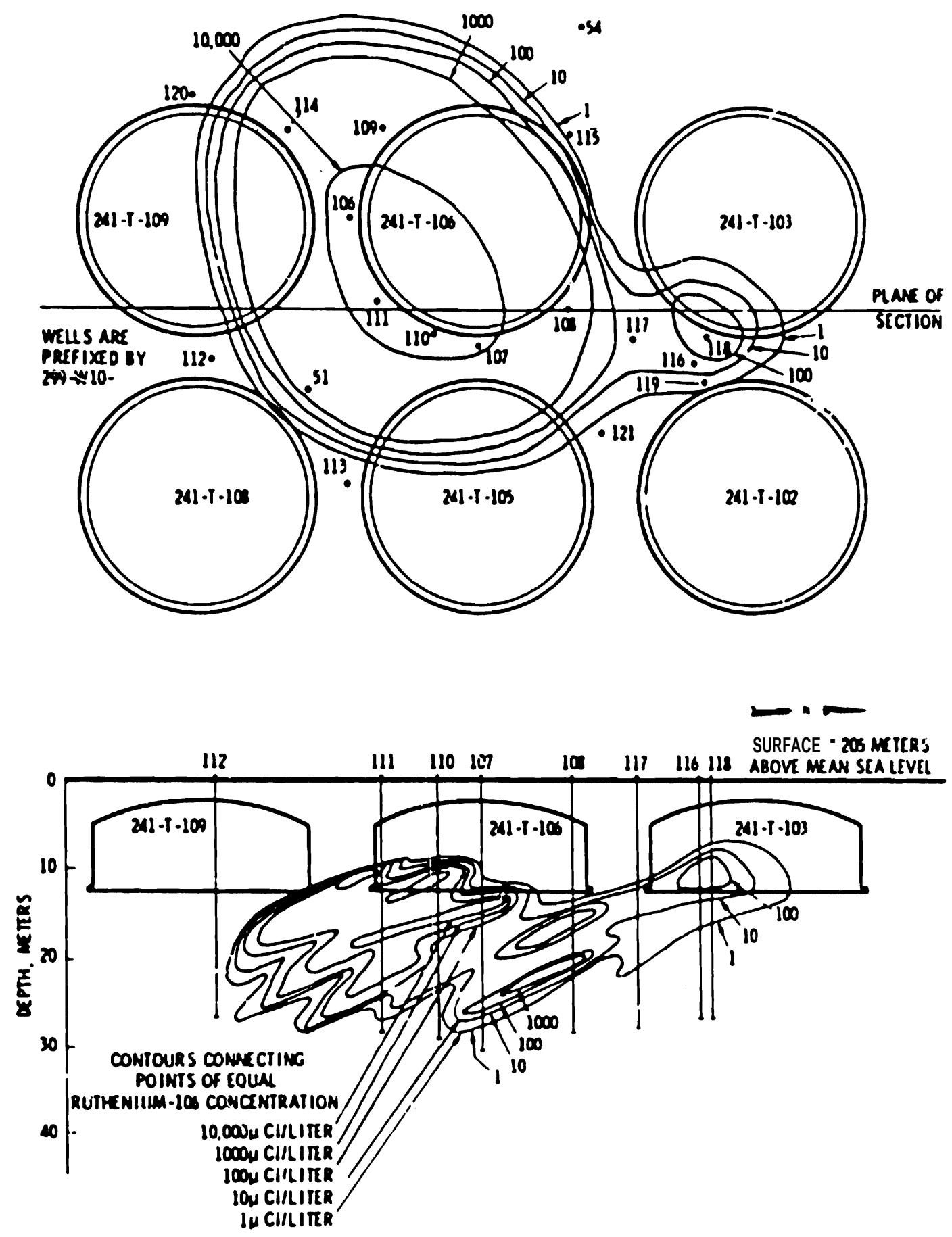

FIGURE 4.2. Vertical Cross Section of the 106Ru Plume (after ARHDO 1973) 


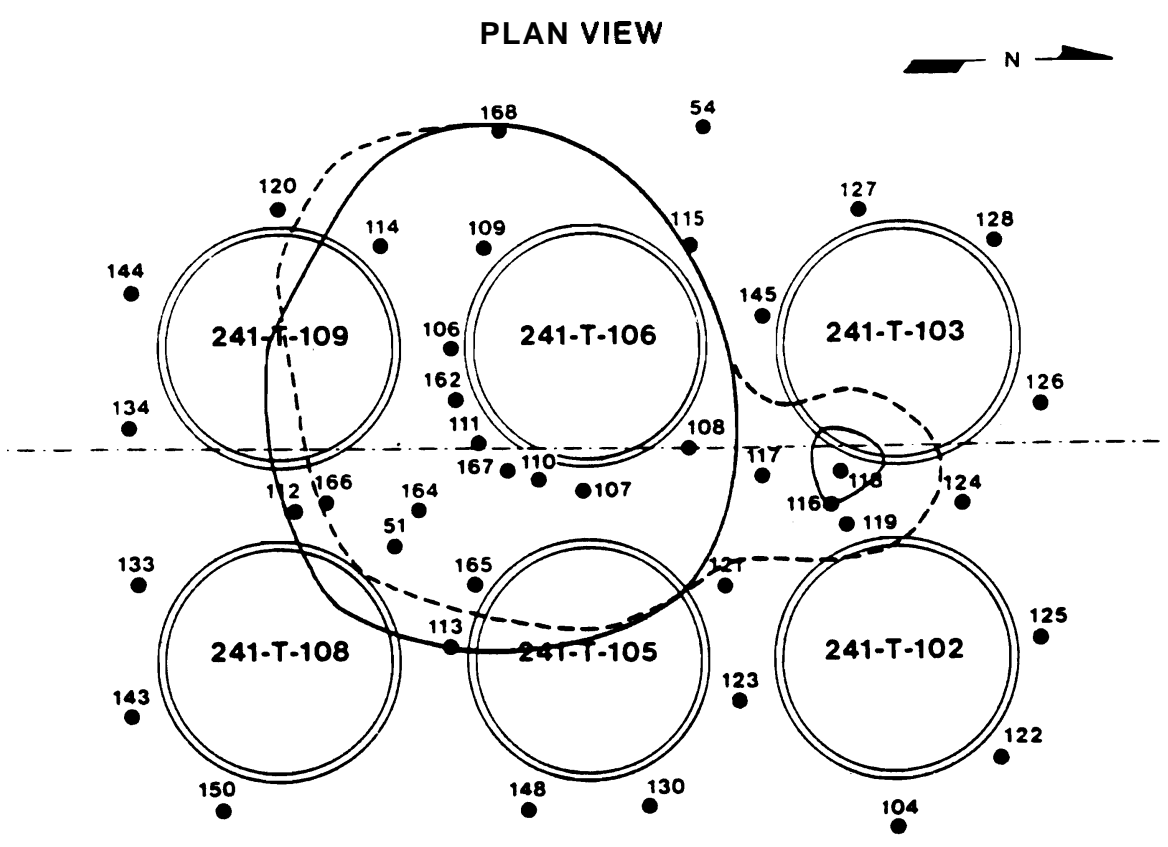

CROSS SECTION VIEW

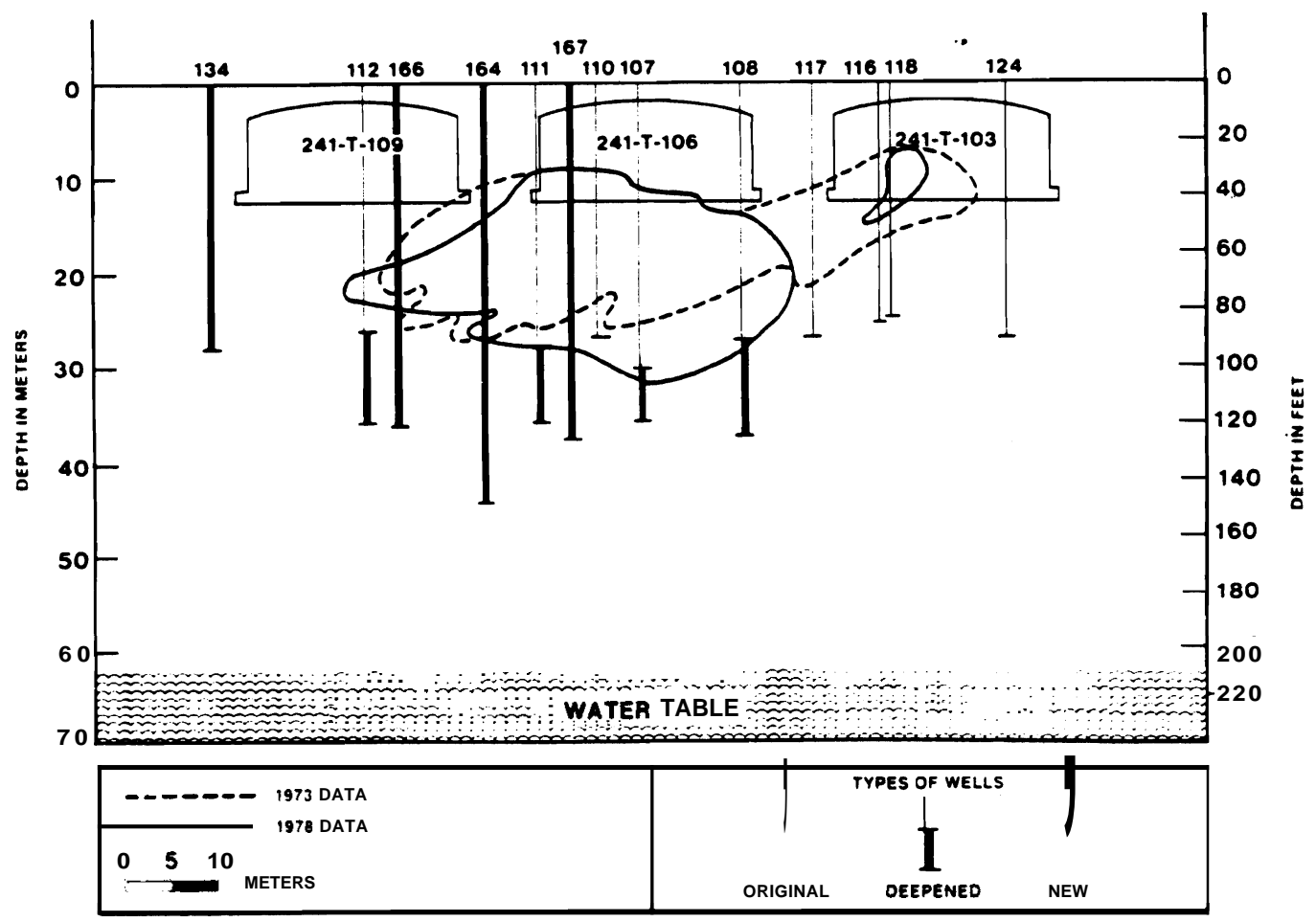

FIGURE 4.3. Plan and Vertical Cross-Sectional Views of the $137 \mathrm{Cs}, 137 \mathrm{Ce}$, and $106 \mathrm{Ru} 1-\mu \mathrm{Ci} / \mathrm{L}$ Volumetric Isopleths in 1978 (after Routson et al. 1979) 
1973 to about $8.4 \times 10^{9} \mu \mathrm{Ci}$ in 1978 . However, the decay process alone is not sufficient to explain the measured stasis of the $1-\mu \mathrm{Ci} / \mathrm{L}$ isopleth of $106 \mathrm{Ru}$ in 1978. As will be indicated later, model simulations fail to reproduce this stasis. 


\subsection{NUMERICAL SIMULATION}

No computer simulation of the 241-T-106 tank leak has previously been published. A simulation with axisymmetric geometry and assumed tank-leak conditions was made by Rockwell Hanford Operations staff, but that study was never published. Most simulations of fluid-flow and contaminant transport in the vadose zone of the Hanford Site have been one-dimensional. In contrast, ground-water flow and contaminant transport in the unconfined aquifer have been extensively simulated (Evans et al. 1988).

\subsection{CONCEPTUAL MODEL}

Leakage from the T-106 tank appears to have been contained within the unsaturated zone. Consequently, the object of this analysis was to focus on contaminant transport through the unsaturated zone. The major stratigraphic subdivisions in the vicinity of the T-106 tank are described in Section 3.1 (see Figure 3.2). These subdivisions are incorporated into the domain of the three-dimensional model. Approximately 115,000 gallons of supernate leaked into this soil column during an approximate 52-day period in the late spring of 1973. A 106Ru plume developed by the summer of 1973, with a horizontal radius of about 15 to $20 \mathrm{~m}$ and extending to a depth of about $20 \mathrm{~m}$ below the base of the tank.

In the horizontal plane, the model domain encompasses an area of about $6,000 \mathrm{~m}^{2}$ centered approximately on the T-106 tank. The model extends vertically about $60 \mathrm{~m}$ to the water table. At this scale, each stratigraphic subdivision within the domain is assumed to be of constant thickness. No flow is allowed across the vertical (sides and ends) boundaries of the domain. Thus, at the scale of the model domain, the flow is vertical. However, locally in the vicinity of the leak, the flow is fully threedimensional. The water table forms the lower boundary for the model. The pressure at this boundary is assumed to remain fixed at the atmospheric value. A uniform infiltration rate is applied to the upper surface of the model. The tank itself is represented as an impervious group of grid cells. 
This treatment allows the infiltrating water to be diverted around the tank. Thus, in a local zone around the perimeter of the tank, the volumetric flux may be significantly enhanced.

\subsection{DISCRETIZATION}

The three-dimensional domain is a region of $3.7 \times 105 \mathrm{~m} 3$, having dimensions of $88 \times 68 \times 62 \mathrm{~m}$. This domain was discretized into a $24 \times 15 \times$ $33 \mathrm{~m}$ grid containing 11,880 cells. The discretization is shown in Figure 5.1 for the $x, y$, and $z$ directions. A variable grid spacing is used in all three dimensions. The grid mesh in the $x$ and $y$ (horizontal) directions is finest $(2 \mathrm{~m})$ near the middle of the domain, where the T-106 tank is located just beneath the surface, and coarsens toward the edges of the model domain.

The model domain is discretized vertically in the $\mathbf{z}$ (vertical) direction, from the surface down to the water table. Each of the five major stratigraphic subdivisions is further subdivided, resulting in a total of 33 cells in the $z$ direction. The grid size varies in the $z$ direction from $0.5 \mathrm{~m}$ near the base of the T-106 tank to $8 \mathrm{~m}$ near the water table.

\subsection{BOUNDARY AND INITIAL CONDITIONS}

The boundary conditions are shown in Figure 5.2. The vertical boundaries around the perimeter of the domain were specified to be no-flow boundaries, based on the assumption of predominantly vertical flow within the unsaturated zone. The upper boundary at the ground surface was specified to be an infiltration-source boundary. An infiltration rate of $0.05 \mathrm{~m} / \mathrm{yr}$ was simulated. Although Gee's (1987) preliminary results indicate that the rate of infiltration of meteoric water for an unvegetated, gravel-covered surface may be higher, $0.05 \mathrm{~m} / \mathrm{yr}$ was used as an initial estimate. This value was estimated as approximately $30 \%$ of precipitation. As noted in section 3.3.1, recharge to the unconfined aquifer may vary from zero to greater-than-average annual precipitation at specific locations of the Hanford Site. The lower boundary at the water table was assumed to be at atmospheric pressure.

Initial conditions were set for hydraul ic head and radionucl ide concentration throughout the model domain. Initially, the matric potential within the unsaturated sediments was assumed to be in equilibrium with a 


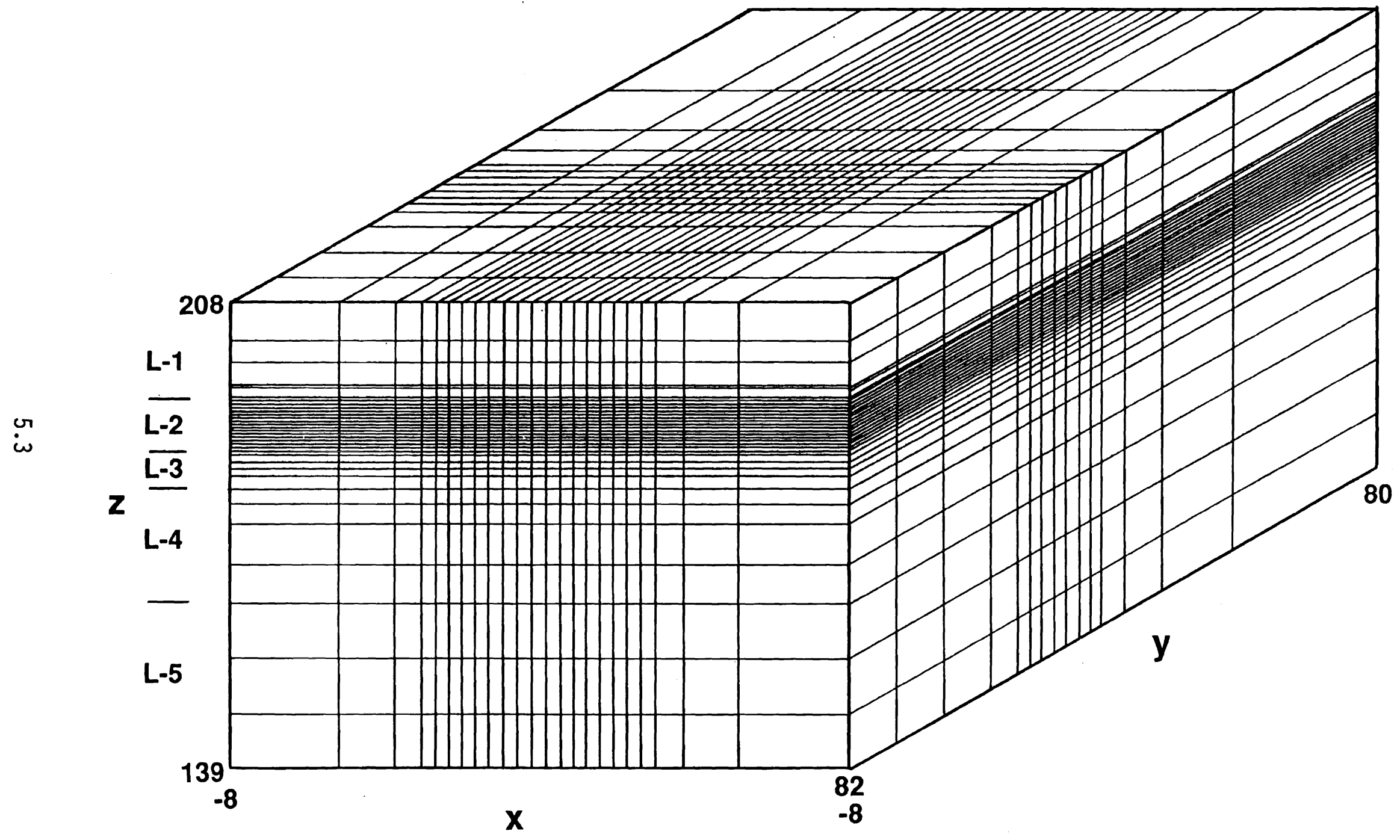

FIGURE 5.1 Discretization of the Three-Dimensional Mode 


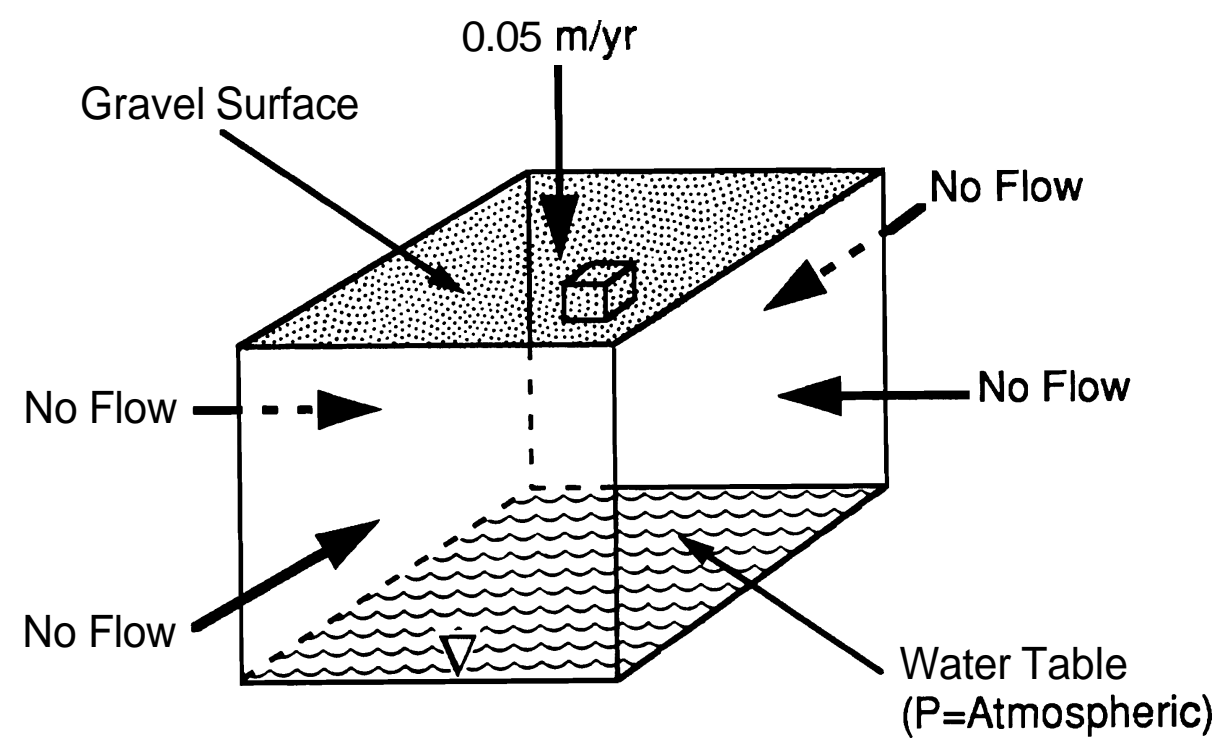

$\mathbf{S 8 9 0 9 0 0 5}$

FIGURE 5.2. Boundary Conditions of the Three-Dimensional Model

constant $0.05 \mathrm{~m} / \mathrm{yr}$ infiltration rate. By assuming approximate unit gradient conditions over a unit area, the hydraulic conductivity becomes approximately equal to the infiltration rate and the matric potential may be estimated for each of the five stratigraphic units from the assigned moisture characteristic curves. The initial condition total hydraulic head was calculated at each node by adding the corresponding elevation (or gravity head) to the matric potential.

The starting time of the simulation was immediately before the start of the leak. The initial concentration of radionuclides was set equal to zero throughout the soil column. Because the tank is impervious, the radionucl ide concentrations inside the tank are immaterial.

\subsection{SOIL HYDRAULIC AND TRANSPORT PROPERTIES}

Although directly measured soi 1 properties for the 241-T-106 site are not currently available, several small data catalogues are available describing moisture retention data for soil samples obtained elsewhere at the Hanford Site. The only soil-property data for the single-shell tank farm are described by Sewart et a1. (1987). These data are for five soil samples collected during excavation of the 210-AP Tank Farm in the 200-East Area. 
The textural descriptions of the samples (Sewart et al. 1987) were compared with descriptions of the five stratigraphic units identified at the T Tank Farm. This comparison is shown in Table 5.1. The analogues were obtained by using a data catalogue containing only a limited amount of soil data. The absence of data specific to the 241-T-106 tank site introduced an undetermined amount of uncertainty into the simulation results.

The moisture retention curves for the five stratigraphic subdivisions in the model are shown in Figures 5.3 through 5.7. The curves show that the soils exhibit a relatively wide range of properties. The corresponding unsaturated hydraulic conductivities (K) for isotropic conditions as a function of volumetric moisture contents $\left(\boldsymbol{\theta}_{\mathrm{s}}\right)$ are also shown for each stratigraphic unit.

An important factor in the simulation is the representation of the tank in the subsurface as a solid object that would divert infiltration. Because the PORFLO-3 code does not allow the assignment of inactive (no-flow) cells within the grid mesh, the tank must be represented using soil properties. The various coefficients used to represent the tank as an essentially impervious object are shown below:

$\mathrm{n}=0$ where $\mathrm{n}$ is porosity

- $\mathrm{K}_{\mathrm{x}}=\mathrm{K}_{\mathrm{y}}=\mathrm{K}_{\mathrm{z}}=1 \times 10-30$ where $\mathrm{K}$ is hydraulic conductivity

$S_{S}=0$ where $S_{S}$ is the specific storage

- $\alpha \mathrm{L}=\alpha \mathrm{T}=1 \times 10-30$ where $\alpha \mathrm{L}$ is longitudinal dispersivity and

$\alpha T$ is transverse dispersivity

- $\mathrm{C}=\mathrm{C}_{\max }$ where $\mathrm{C}$ is concentration.

The porosity is set to zero. The specific storage $\left(S_{\boldsymbol{s}}\right)$ is also set to zero, and the hydraulic conductivity $\left(\mathbf{K}_{\mathbf{x}}\right)$ is given a nominal but nonzero value.

Transport coefficients were assumed for each of the five stratigraphic units. For all units, the Fickian molecular diffusion coefficient (D) was held constant at $1 \times 10-5 \mathrm{~m} 2 /$ day and longitudinal and transverse dispersivity at $1.0 \mathrm{~m}$ and $0.1 \mathrm{~m}$, respectively. For those model simulations that address retardation, a distribution coefficient of $5 \times 10^{-7} \mathrm{~m} 3 / \mathrm{g}(0.5 \mathrm{~mL} / \mathrm{g})$ was used for $106 \mathrm{Ru}$ and $1 \times 10^{-4} \mathrm{~m} / \mathrm{g}(100.0 \mathrm{~mL} / \mathrm{g})$ for $137 \mathrm{Cs}$. Continued work is needed to quantify contaminant transport properties of Hanford Site soils; the values used in the simulation were only estimates. 
TABLE 5.1. T Tank Farm Soi 1 Properties and the Corresponding 241-AP Soil Catalogue Properties Used in the Modeling Analysis

T Tank Farm Soi 1 Properties

Layer 1: Silty sandy gravel backfill

Layer 2: Pebbly very coarse to medium sand

Layer 3: Coarse to medium sand

Layer 4: Silty, fine to very fine sand and sandy silt with calcareous, cemented sublayers

Layer 5: Sandy gravel
Corresponding 241-AP Tank Farm Excavation Soil Description (after Sewart et al. 1987 p. 5.7)

AP Soi 1 1: Sandy gravel, Unconsol idated, horzontal ly bedded, very coarse sand with very fine to very coarse pebbles

AP Soil 2: Sand. Well-consolidated, horizontally bedded, medium to coarse sand

AP Soil 4: Gravelly sand. Very unconsolidated coarse sand with pebbles and small cobbles

AP Soil 5: Silty sand. Very well consolidated, horizontally bedded very find sand and silt

AP Soi 1 1: Sandy gravel. Unconsolidated, horizontally bedded, very coarse sand with very fine to very coarse pebbles 


\section{Stratigraphic Subdivisions 1,5}

AP-1G
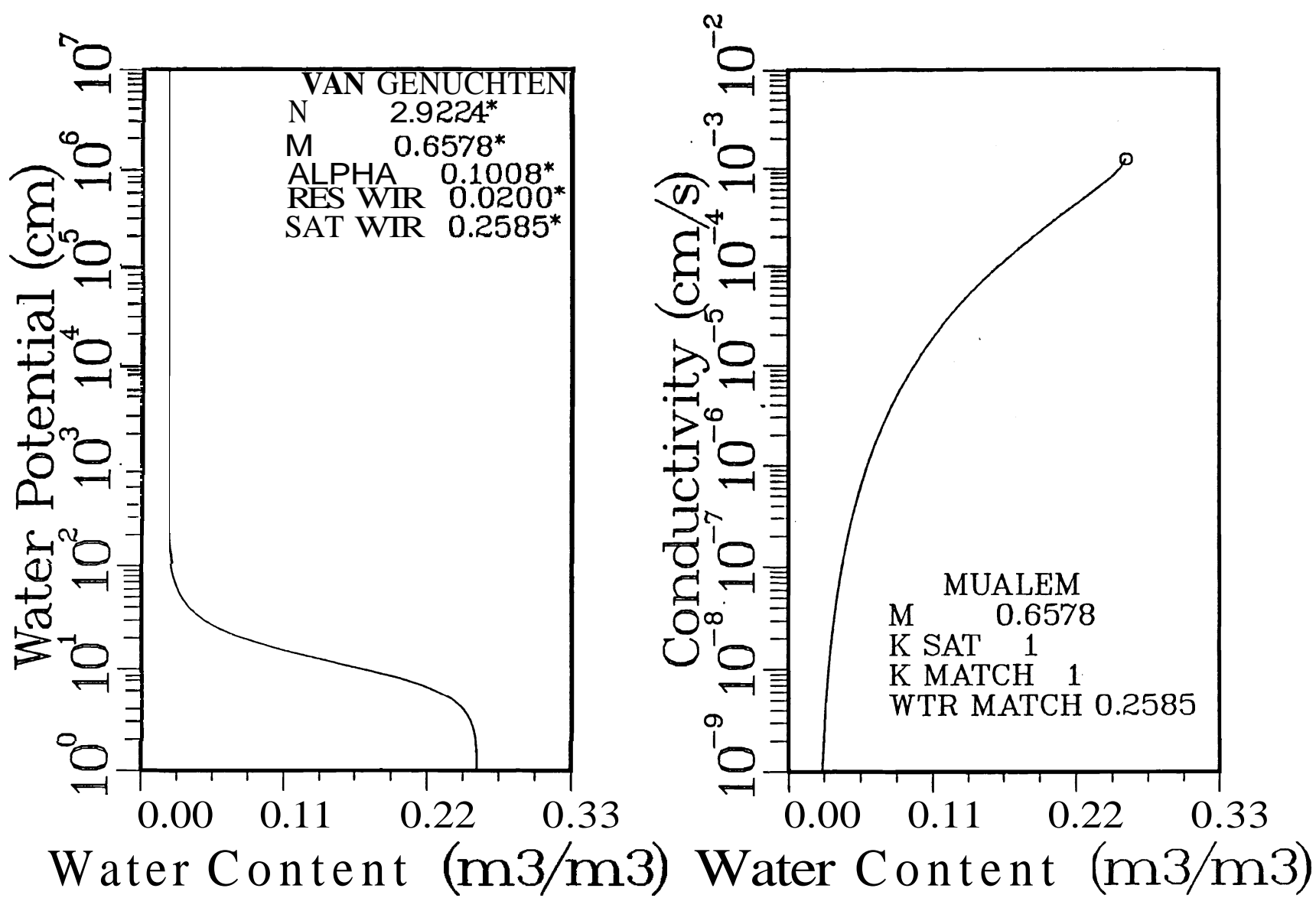

FIGURE 5.3. Moisture Retention Curves Identified for Stratigraphic Units One and Five at the T Tank Farm 


\section{Stratigraphic Subdivision 2}

AP-2
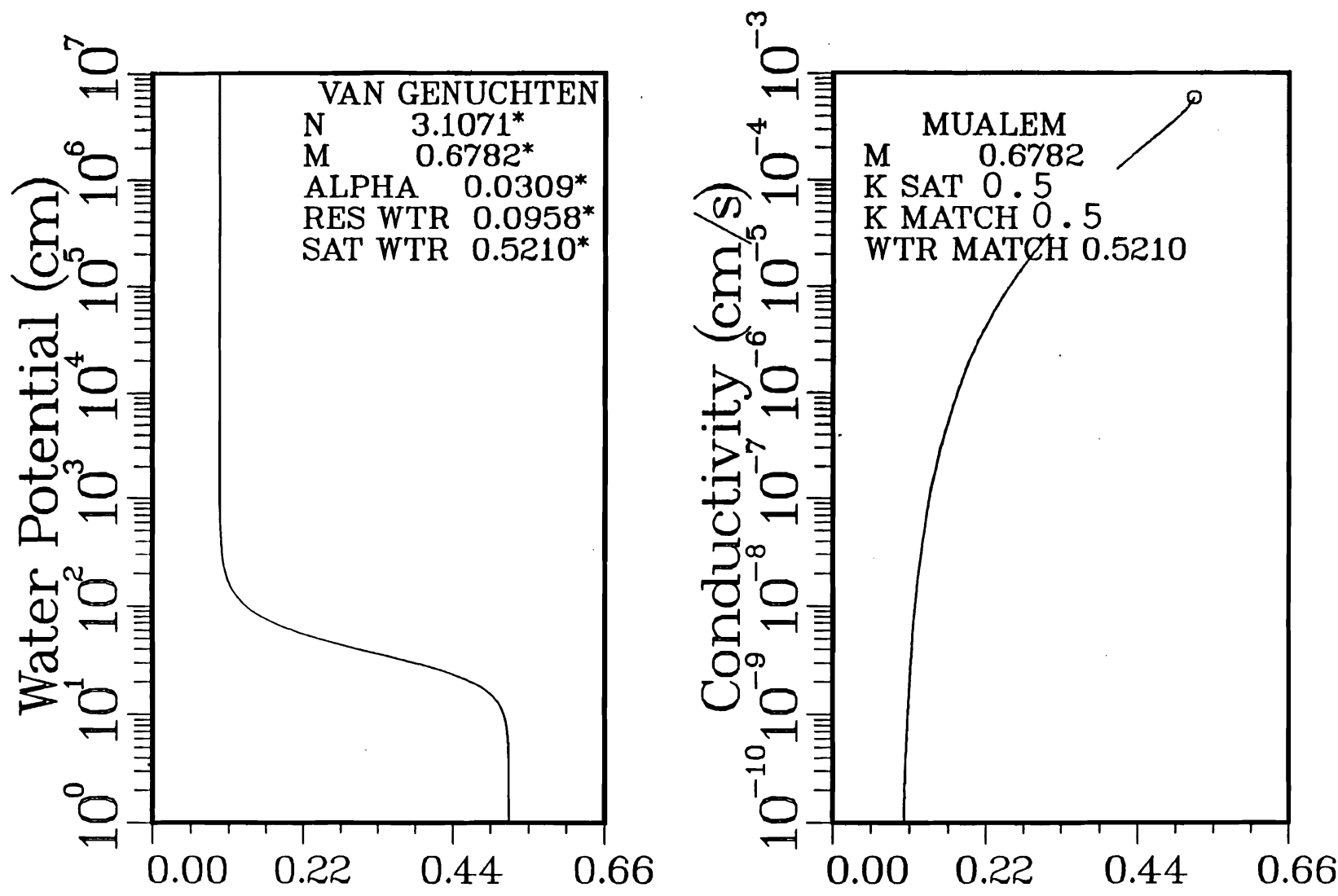

Water Content (m3/m3) Water Content (m3/m3)

FIGURE 5.4. Moisture Retention Curves Identified for Stratigraphic Unit Two at the T Tank Farm 


\section{Stratigraphic Subdivision 3}

AP - 4G

ir
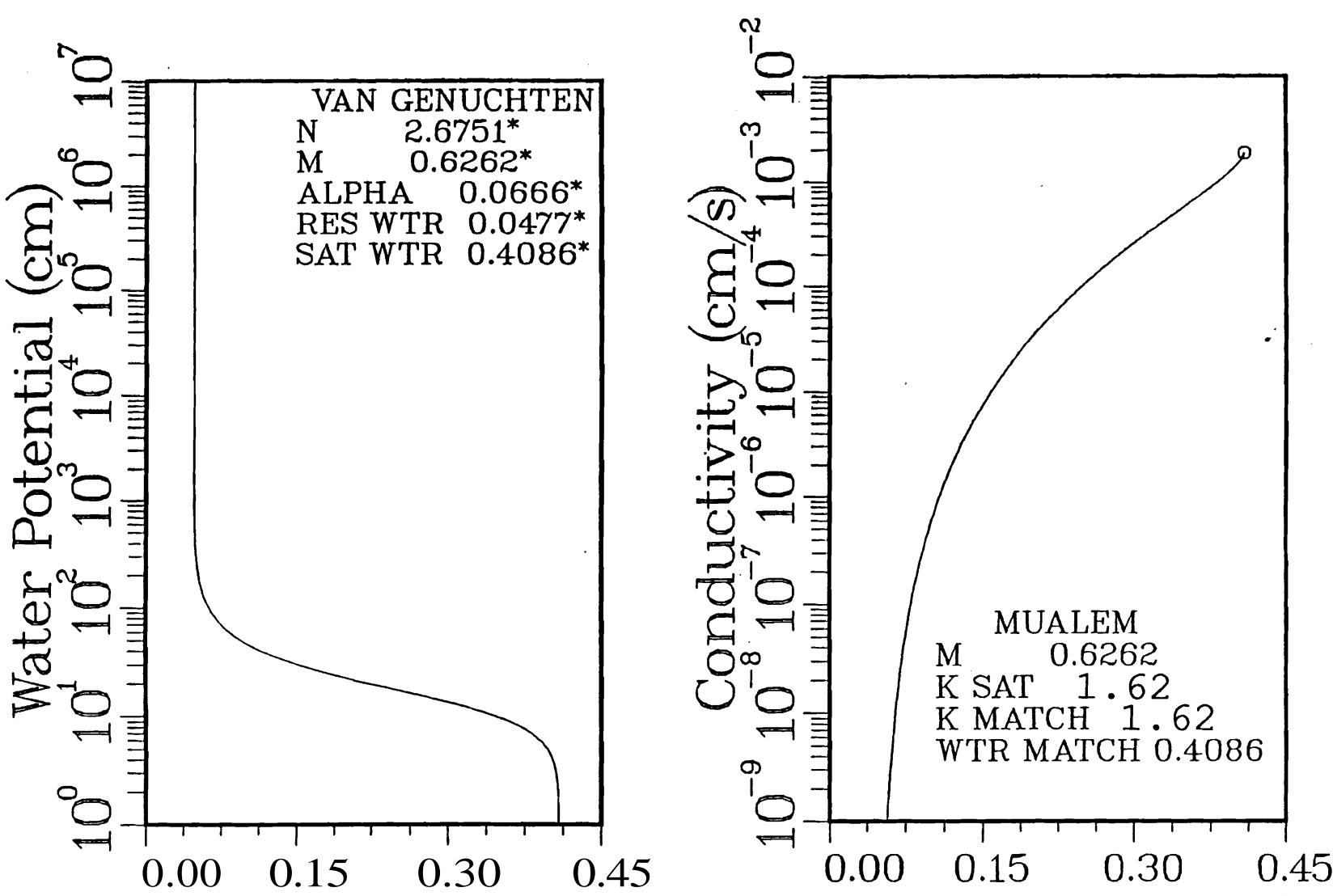

Water Content (m3/m3) Water Content (m3/m3)

FIGURE 5.5. Moisture Retention Curves Identified for Stratigraphic Unit Three at the T Tank Farm 


\section{Stratigraphic Subdivision 4}

\section{AP -5}

v
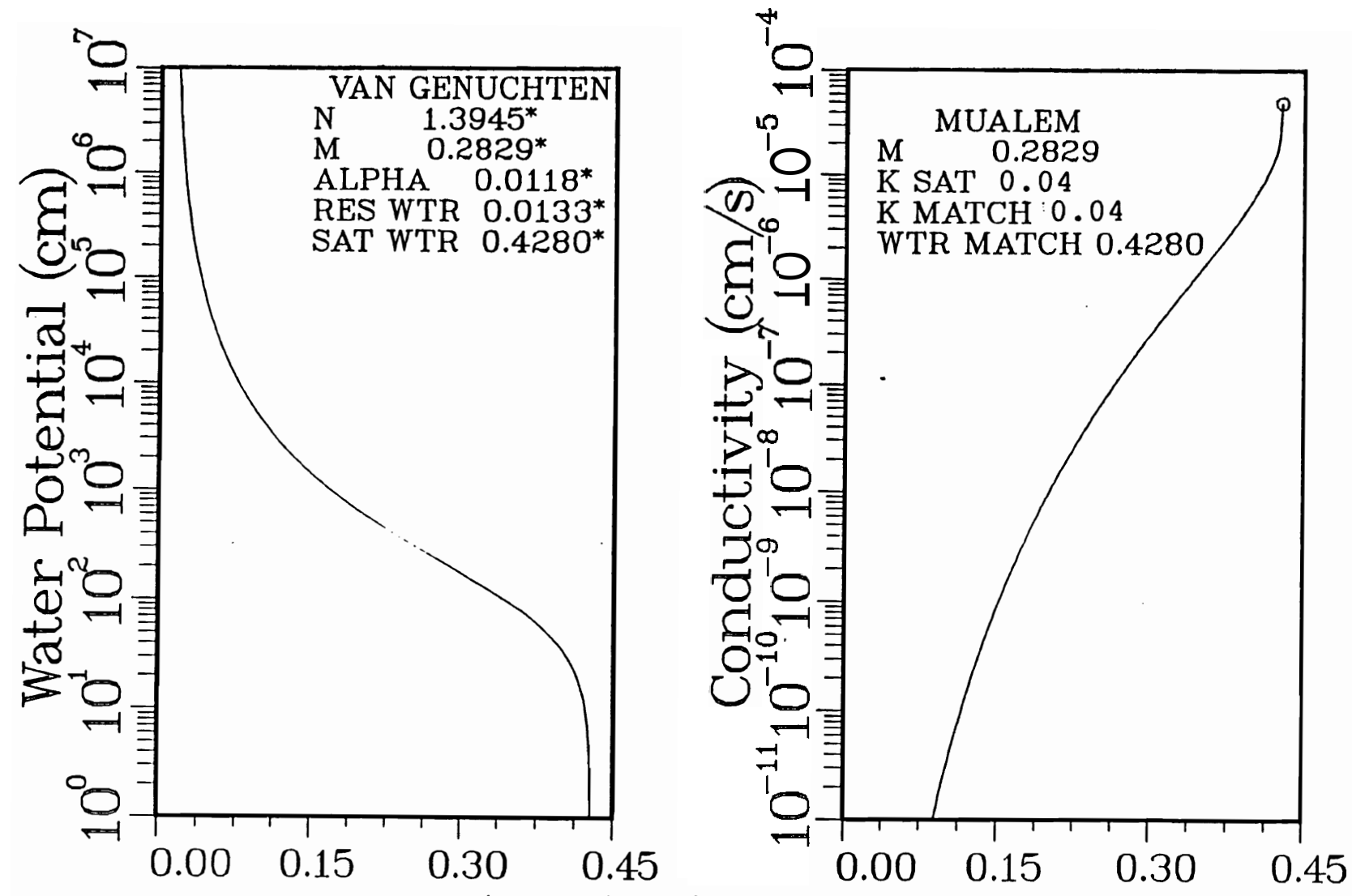

Water Content (m3/m3) Water Content (m3/m3)

FIGURE 5.6 Moisture Retention Curves Identified for Stratigraphic Unit Four at the T Tank Farm 


\section{Hydraulic Property Distribution 1}

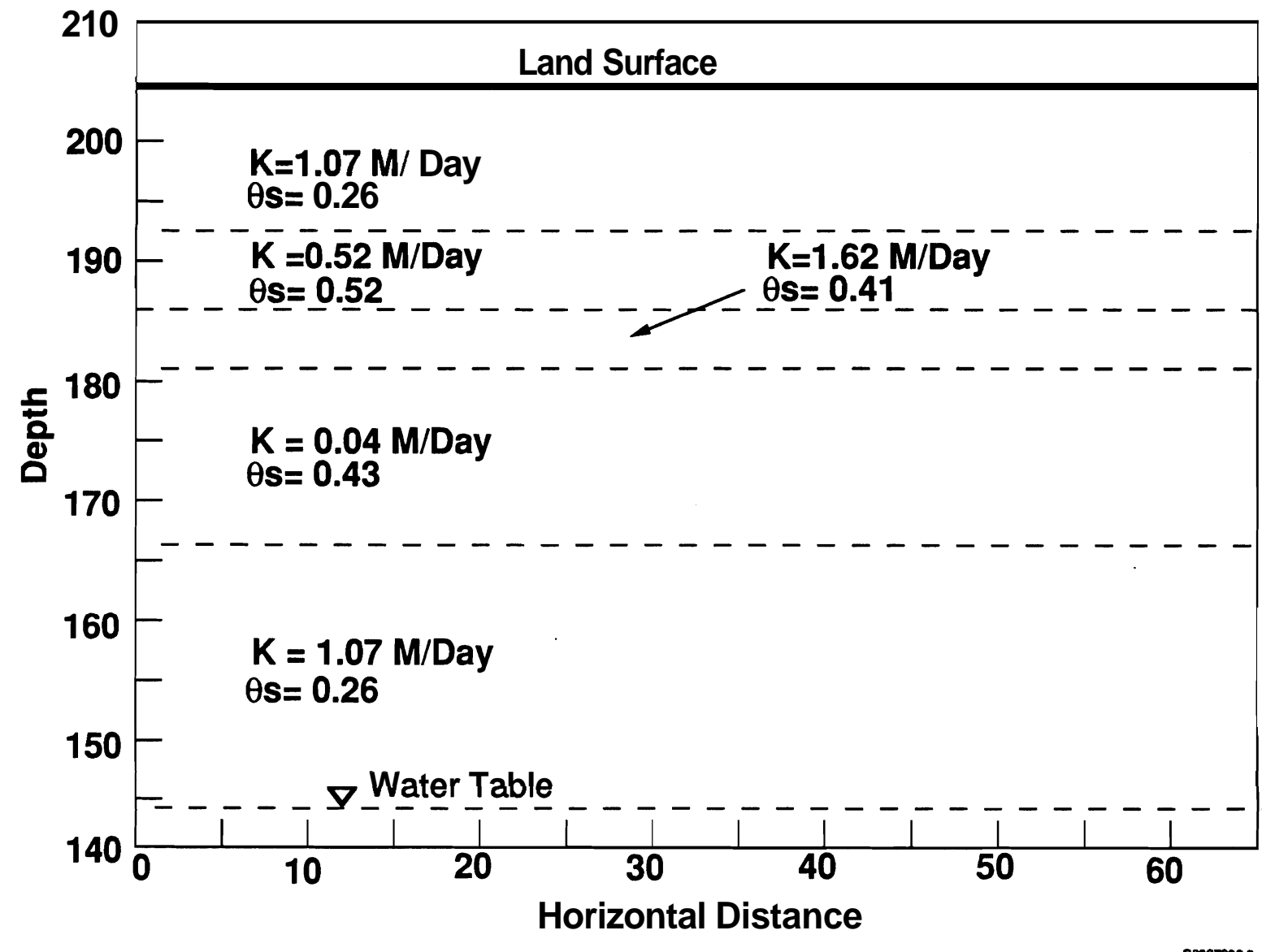

FGURE 5.7. Hydraul ic Coefficients for the Five Stratigraphic Units Identified at the T Tank Farm

\subsection{SOURCE TERMS}

The source terms for radionuclides are based on their concentrations in the supernate (Table 4.1). These concentrations were applied to the leak volume of 115,000 gallons for a duration of 52 days to generate a contaminant source term. The total inventory of about $2.7 \times 1011 \mu \mathrm{Ci}$ of $106 \mathrm{Ru}$ results in a source term of $5.1 \times 10^{9} \mu \mathrm{Ci} /$ day during the 52-day leak. The corresponding liquid flux is about $8.4 \mathrm{~m}^{3} /$ day and is assumed to have the viscosity of water rather than supernate. The total inventory of $137 \mathrm{Cs}$ of about $3.8 \times 1010 \mu \mathrm{Ci}$ results in a source term of about $7.4 \times 108 \mu \mathrm{Ci}$ /day during the 52-day leak. The total liquid flux is assumed to remain constant for each constituent analyzed. 



\subsection{RESULTS OF SIMULATIONS}

The 241-T-106 tank leak was simulated to portray contaminant plumes for $106 \mathrm{Ru}$ and $137 \mathrm{Cs}$. The leak was assumed to continue for 52 days, after which the source of both liquid and contaminant was shut off. For the first series of simulations, the soil-moisture properties listed in a Hanford Site soil property data catalogue (Sewart et al. 1987) were used. The intent was to vary some of the input parameters in subsequent simulations as needed to better approximate the distribution of radionuclides in the soil column, as inferred from gamma spectrometry measurements in 1973 at a time approximately 100 days after the beginning of the leak. Using the calibrated properties, simulation continued through 1990 to estimate the current distribution of the plume.

\subsection{SOIL MOISTURE MOVEMENT}

The PORFLO-3 code provides output for soil moisture in terms of the degree of saturation for each time step. The two major sources of moisture in the simulations were infiltration from precipitation and the fluid introduced by the tank leak. The estimates of initial soil suction were based on unit gradient calculations for an average recharge flux of $0.05 \mathrm{~m} / \mathrm{yr}$, as discussed in Section 5.3. However, the initial soil suctions are only estimates and do not account for the additional flux adjacent to the tank that may result from the diversion of water around the domed top. The leak itself may be expected to produce a saturated slug of fluid that would move predominantly downward and dissipate by increasing the relative saturation of the underlying sediments. Consequently, the major features of interest with respect to the moisture movement and redistribution are the infiltration of meteoric water around the tank and the movement of the leaked fluid.

The redistribution of the leaked fluid is shown in Figures 6.1 through 6.6. Figure 6.1 shows the leak at a time of 150 days, or about 100 days after the free liquids in the tank were pumped out. The sediments immediately below the tank have begun to drain. The zone of higher saturation resulting from the leaked tank fluid is about $15 \mathrm{~m}$ below the base of the 


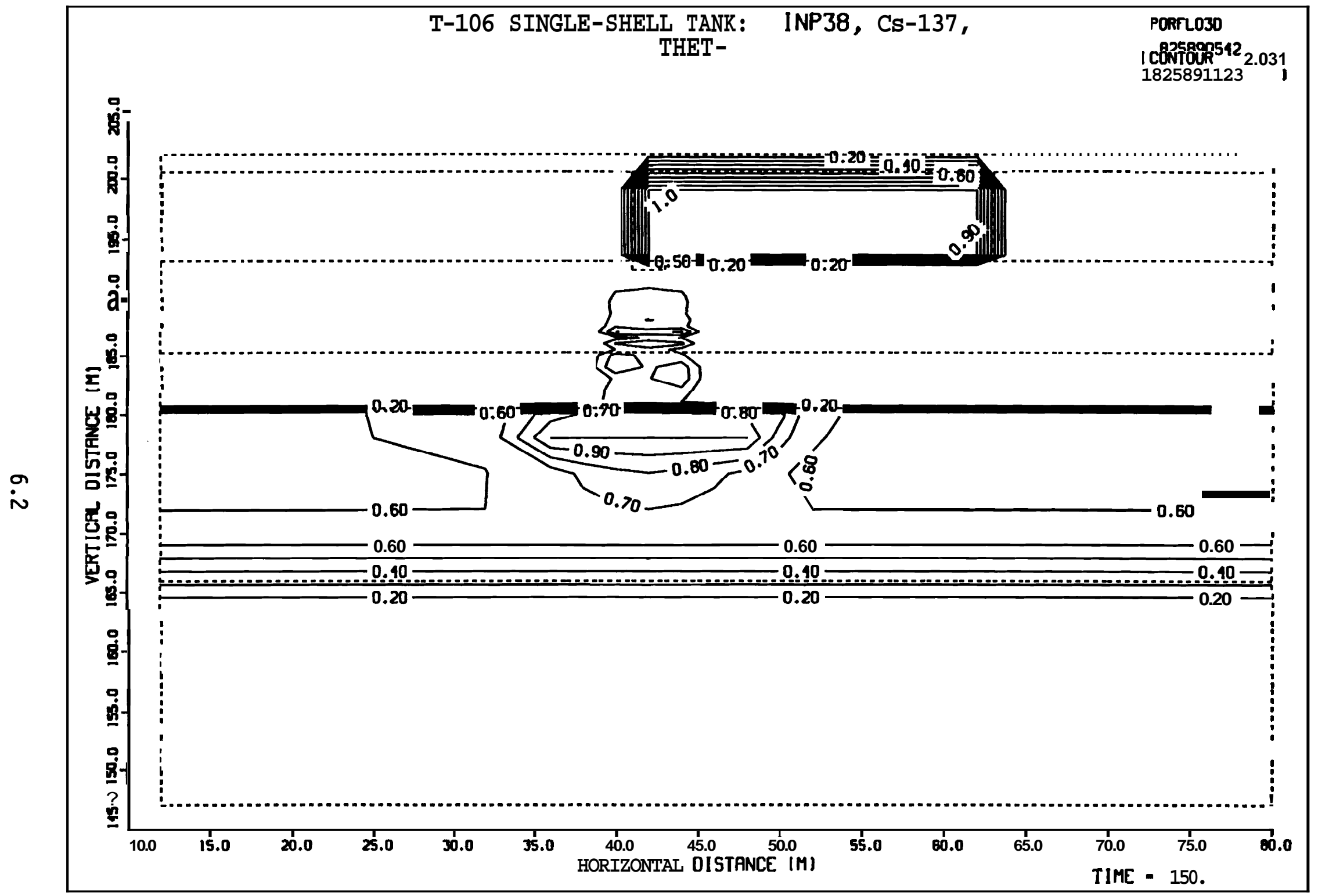

FIGURE 6.1. PORFLO-3 Simulation of Relative Saturation at 150 Days (Vertical Cross Section) 


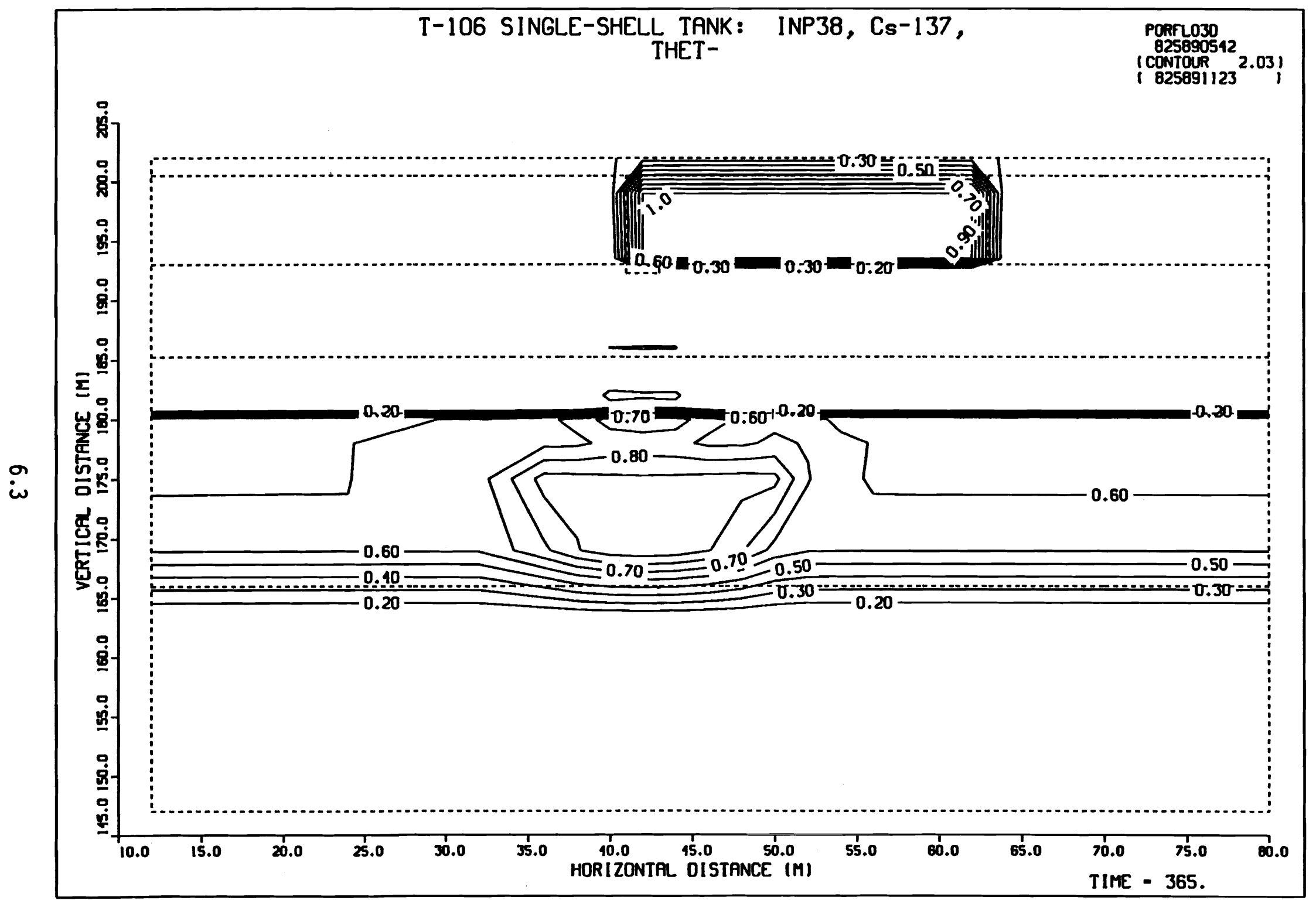

FIGURE 6.2 PORFL0-3 Simulation of Relative Saturation at 365 Days (Vertical Cross Section) 


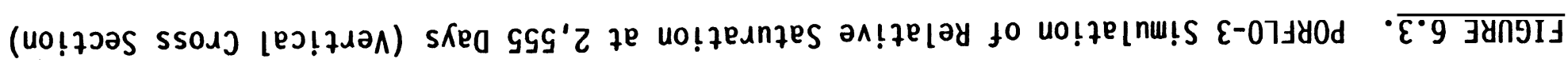

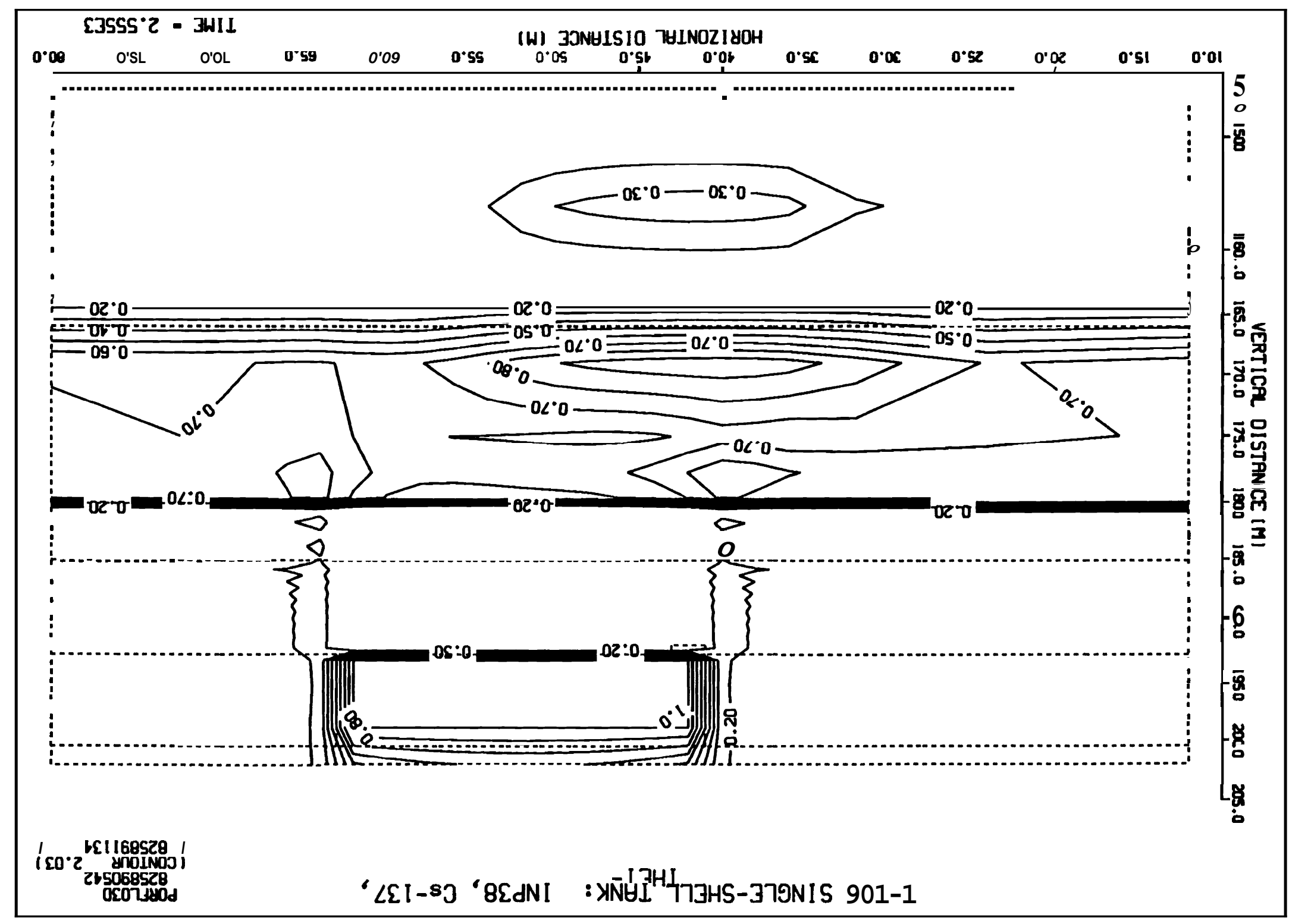




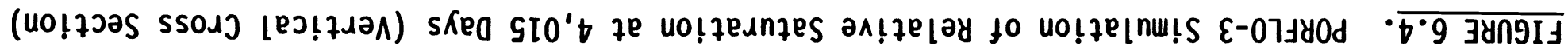

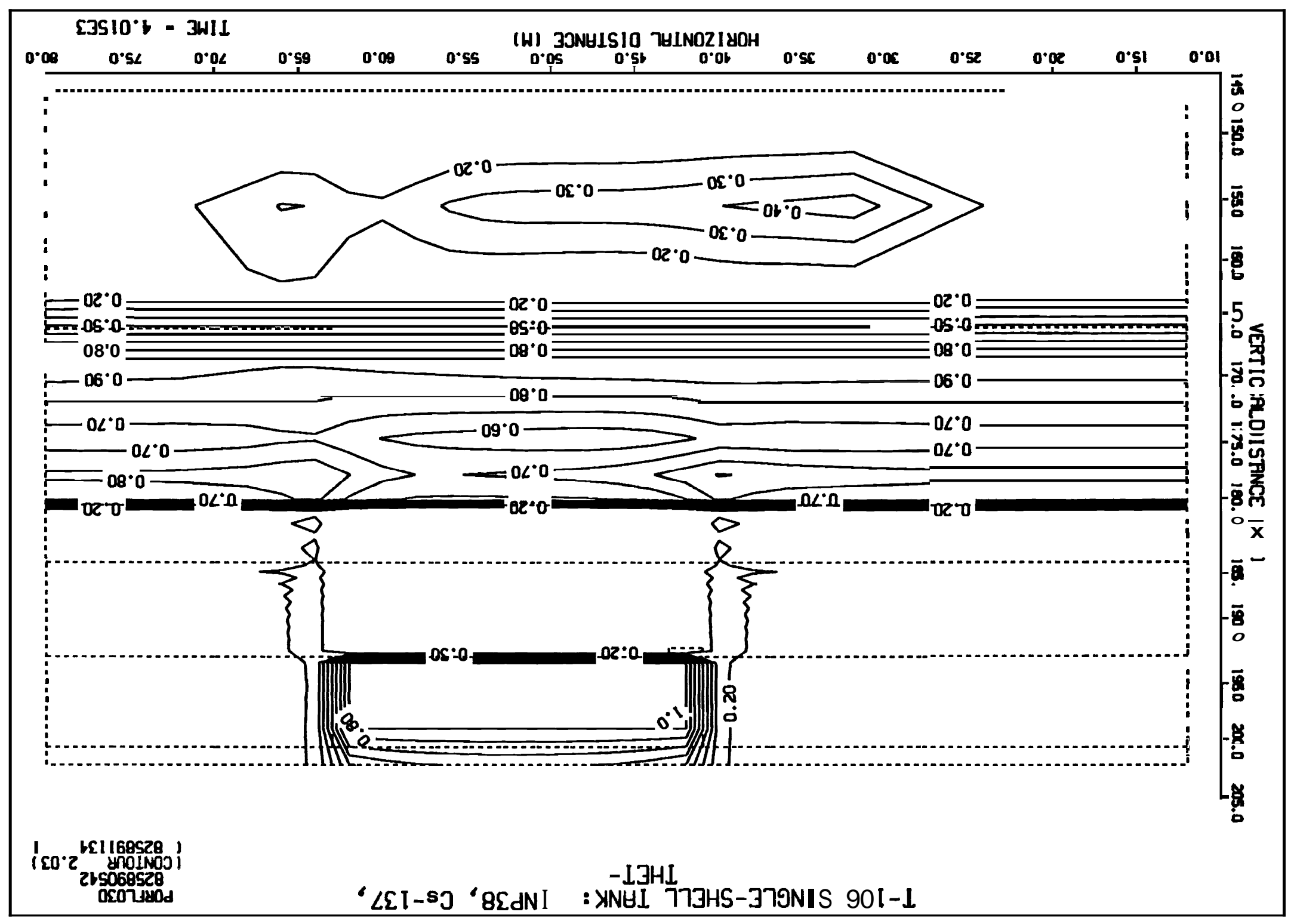




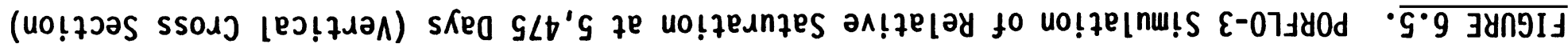

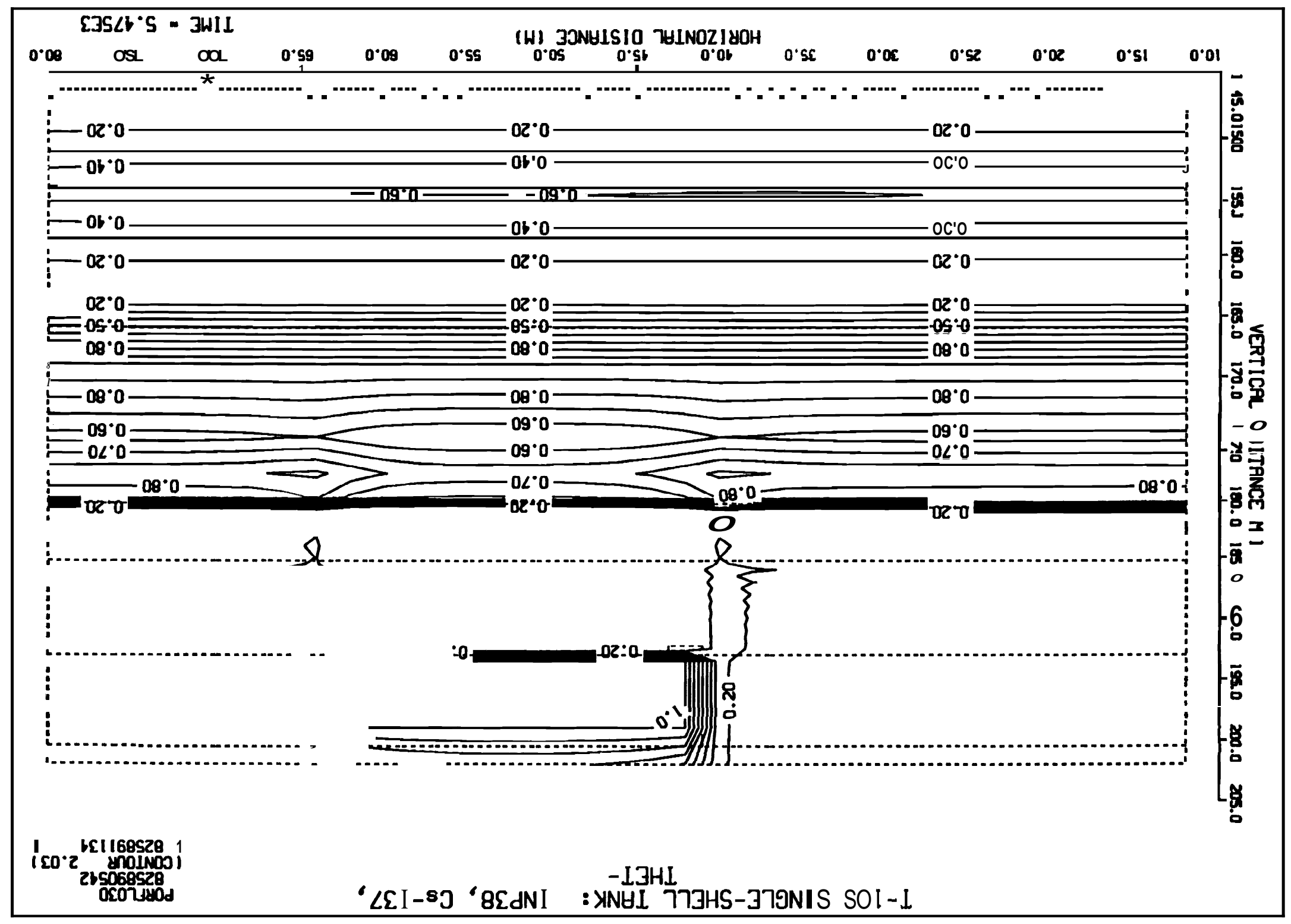




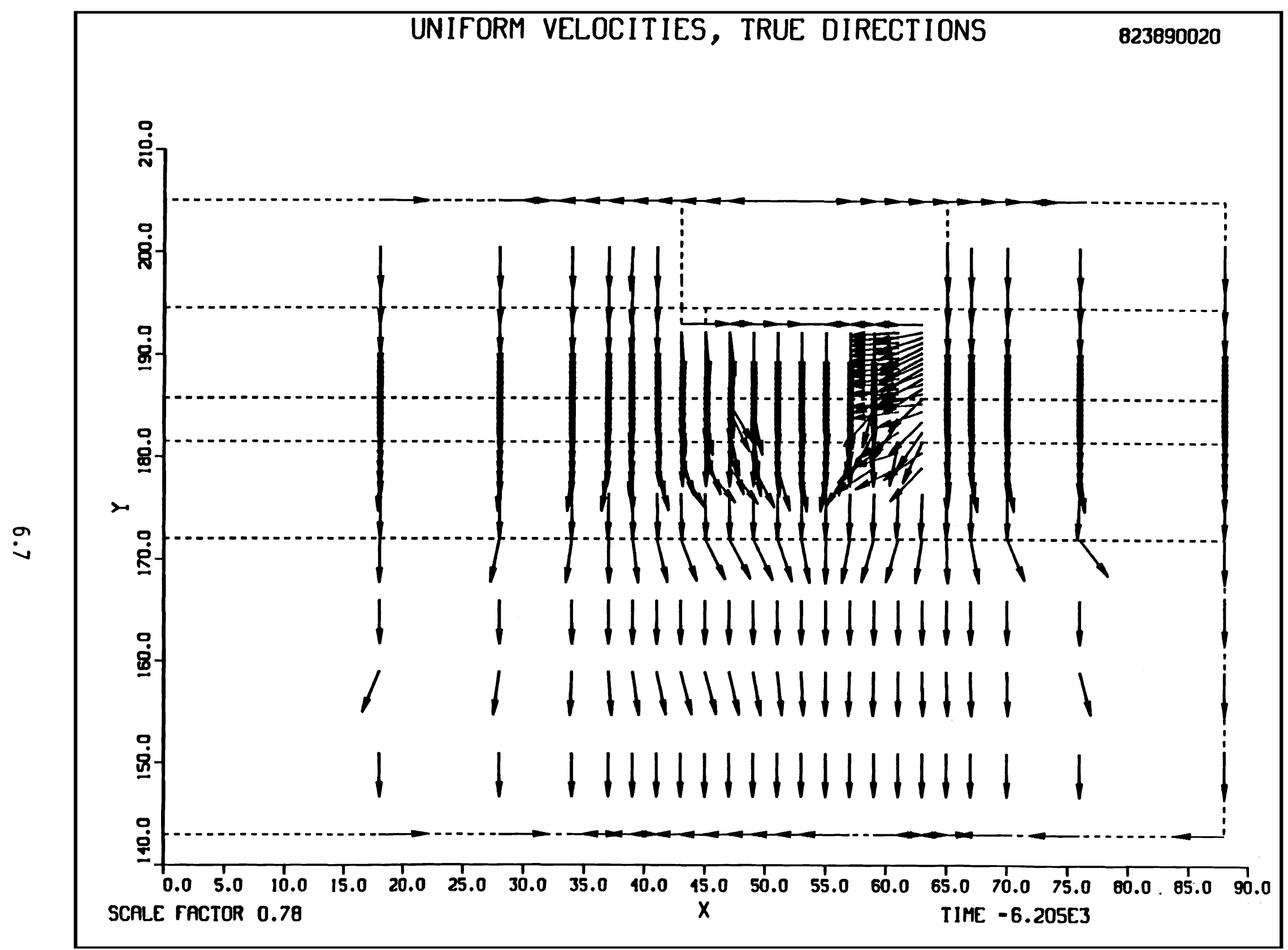

FIGURE 6.6. PORFL0-3 Simulation of Water Velocities at 00 Days (Vertical Cross Section) 
tank in the top of stratigraphic unit 4 (see Figure 3.2). Unit 4 has a lower porosity than unit 3 and a much lower saturated hydraulic conductivity; these factors can be expected to inhibit spread of the fluid. The increase in saturation near the top of the finer-grained sediments in unit 4 appears to be a reasonable result. Isaacson (1982) reported saturated or near-saturated conditions in T Tank Farm dry wells at approximately this depth.

At the later times shown in Figures 6.2 through 6.5, the slug of fluid continues to drain and dissipate. Also evident at later times is an increase in saturation from infiltrating water diverted along the wall of the tank. Velocity vectors showing the direction of water movement in the same cross section (Figure 6.6) indicate that water is moving laterally across the dome of the tank, down the tank wall, and perhaps refracting slightly as it enters the sediments below the tank. These results suggest that the initial conditions based on a $0.05 \mathrm{~m} / \mathrm{yr}$ rate of infiltration of meteoric water are not a good assumption for the vicinity of the tank. Diversion of water around the tank is likely to elevate soil moisture conditions in the vicinity of the tank. Given a surface area of about $410 \mathrm{~m}^{2}$ for the top of the tank, the volume of water that would be diverted during the 30 years prior to the leak would be about 1.5 leak volumes. Consequently, the resulting increase in soil moisture would tend to facilitate the movement of fluid leaking from the tank. A better initial condition would be to approximate the steadystate moisture flux around the tank prior to simulating the leak.

\subsection{RUTHENIUM-106 PLUME}

The results for ${ }^{106} \mathrm{Ru}$, using the soil catalogue properties, are shown in vertical and horizontal cross section in Figures 6.7 and 6.8. These results indicate a migration of the $1-\mu \mathrm{Ci} / \mathrm{L}$ isopleth for $106 \mathrm{Ru}$ to a depth of about $40 \mathrm{~m}$ below the tank by 150 days after the beginning of the leak. The magnitude of this simulated migration is about twice that observed in the dry wells adjacent to the tank, as reported by Routson et al. (1979). Although discrepancies in the plume measurements may result from the absence of measurements under the tank and conversion of gamma counts to concentrations, for the purpose of this analysis the 1973 data on the extent of the plume 


\section{1-T-106 Tank Leak: Vertical Profile (Nominal Soil Profile)}

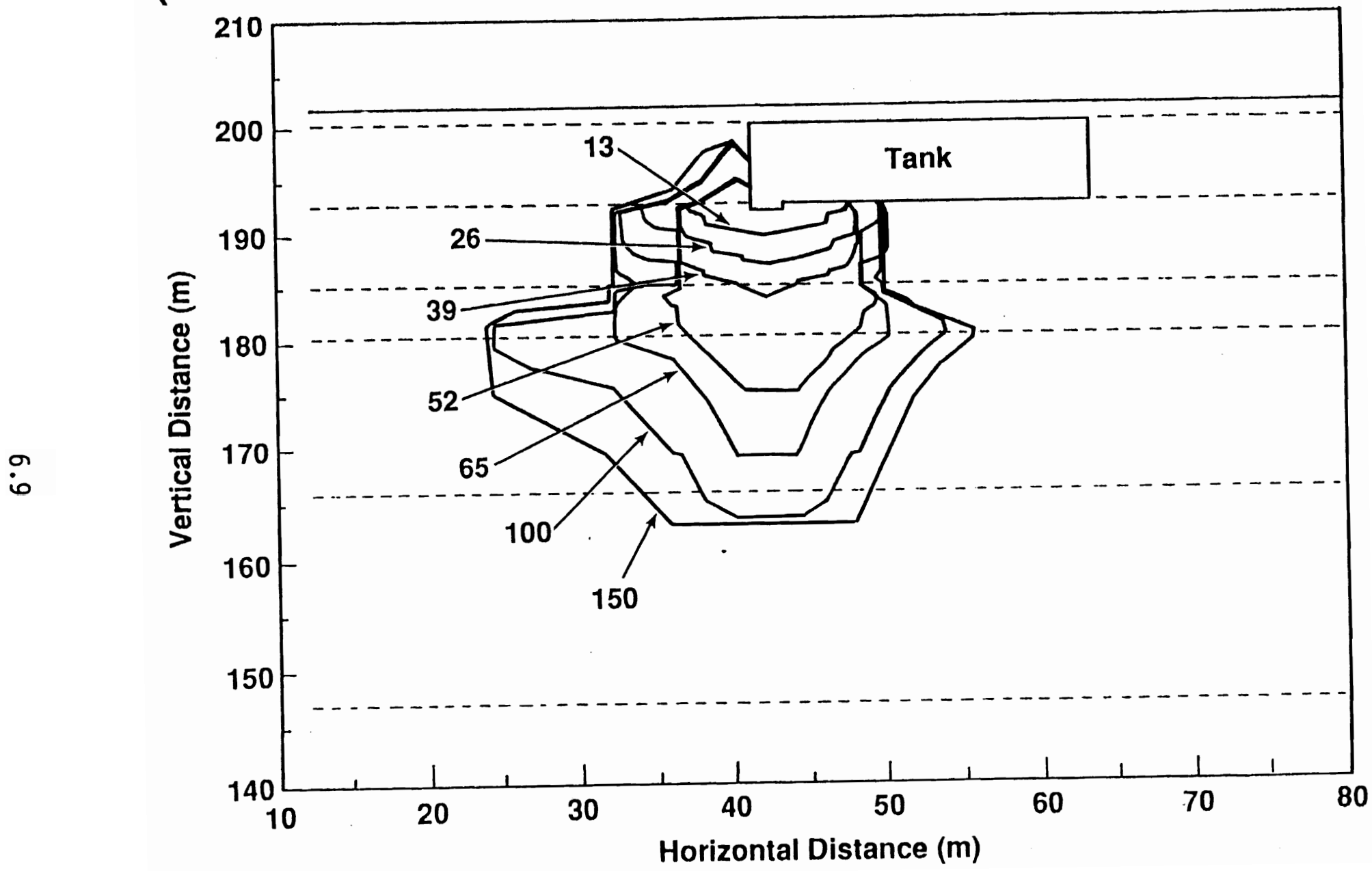

FIGURE 6.7. PORFL0-3 Simulation of the Vertical Extent of the 106Ru 1- $\mu \mathrm{Ci} / \mathrm{L}$ Isopleth Using Data from Field Measurements 


\section{1-T-106 Tank Leak: Horizontal Profile (Nominal Soil Profile)}

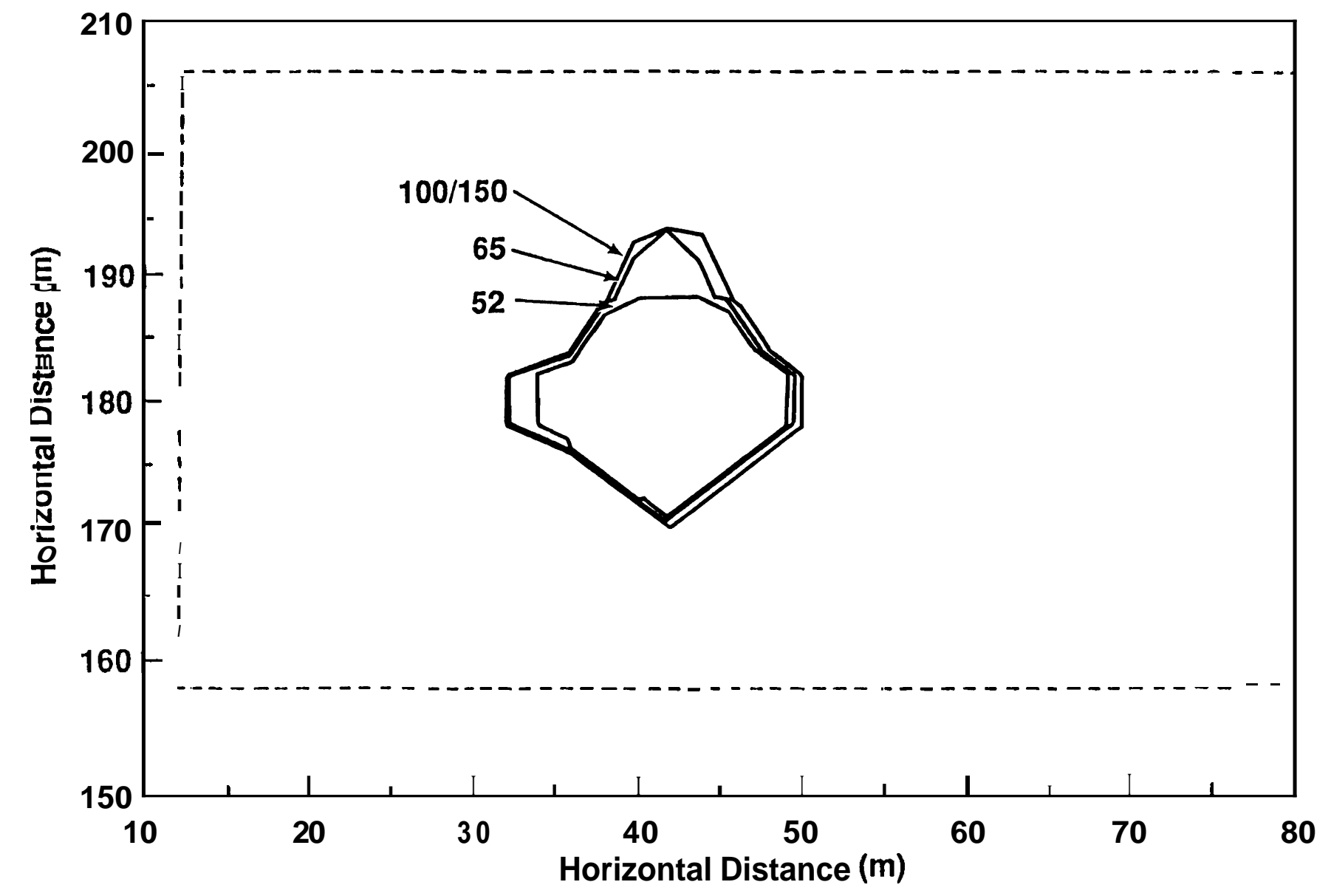

FIGURE 6.8. PORFLO-3 Simulation of the Horizontal Extent of the 106Ru 1- $\mu \mathrm{Ci} / \mathrm{L}$ Isopleth Using Data from Field Measurements 
are assumed to be correct. The rate of plume migration in the vertical direction that can be inferred from the measured extent of the plume is, therefore, slower than that indicated by the simulation results. The horizontal cross section shown in Figure 6.8 is about $5 \mathrm{~m}$ below the base of the tank and indicates a $1-\mu \mathrm{Ci} / \mathrm{L}$ isopleth for $106 \mathrm{Ru}$ of about $30 \mathrm{~m}$ in diameter. This dimension compares favorably with a diameter of 30 to $40 \mathrm{~m}$ of the measured horizontal spread reported by Routson et al. (1979).

Using the simulation results shown in Figures 6.7 and 6.8, several adjustments in the input data were made to better match the measured vertical extent of the 106Ru plume. First, the vertical hydraulic conductivity $\left(K_{z}\right)$ was reduced by a factor of two. The lower value of vertical hydraulic conductivity can be justified because the viscosity of the supernate liquid is higher than that of water. In addition, a factor of two is within the range of uncertainty that would be expected to result from the hydraulic anisotropy of the sediments.

Vertical and horizontal cross sections of the 106Ru plume simulation using the adjusted Kd are shown in Figures 6.9 through 6.11 for times within 1 year of the leak. The $1-\mu \mathrm{Ci} / \mathrm{L}$ is opleth for $106 \mathrm{Ru}$ was located approximately $20 \mathrm{~m}$ below the base of the tank 150 days after the leak; this is in agreement with measurements reported by ARHCO (1973) and Routson et al. (1979). The diameter of the horizontal extent of the plume remains at approximately $30 \mathrm{~m}$, which also compares favorably with the measured extent. Consequently, the simulation appears to be reasonably well calibrated to the 1973 data.

Simulations were subsequently made for the time period through 1990 to estimate the current extent of the plume. Figures 6.12 and 6.13 show the vertical and horizontal extent of the plume for several years up to 1990. The simulations show that the $1-\mu \mathrm{Ci} / \mathrm{L}$ is opleth for $106 \mathrm{Ru}$ has migrated through much of the soil column above the water table by the early 1980s.

Radioactive decay then appears to reduce the extent of the plume through the remainder of the time. However, the simulation predicts that the $1-\mu \mathrm{Ci} / \mathrm{L}$ isopleth for ${ }^{106 R u}$ will encompass a relatively large part of the soil column. This result appears to be a consequence of the large initial inventory of 


\section{1-T-106 Tank Leak: Vertical Profile}

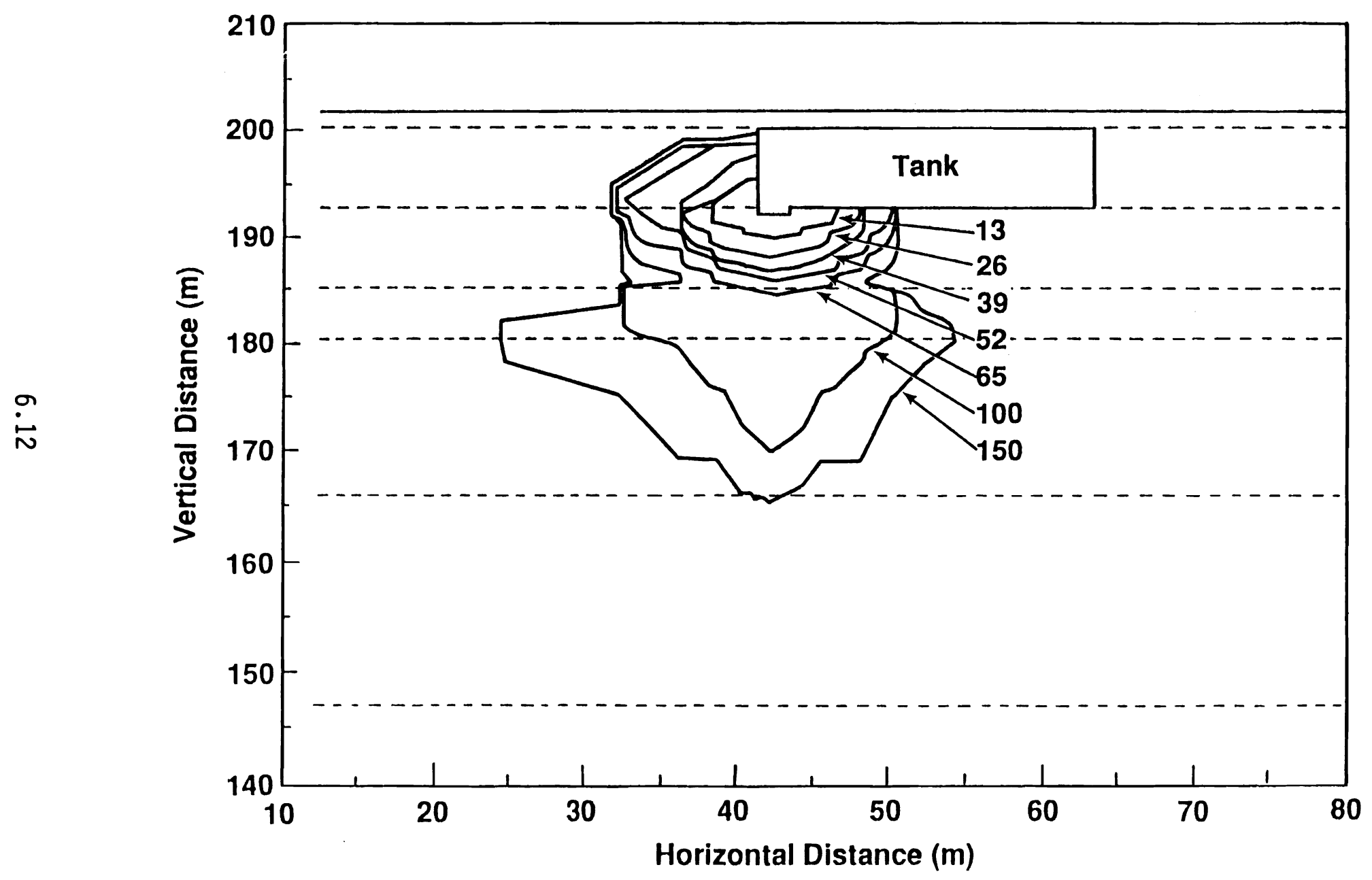

FIGURE 6.9 PORFL0-3 Simulation of the Vertical Extent of t[e 106Ru 1- $\mu \mathrm{Ci} / \mathrm{L}$ Isopleth With Adjusted Vertical Hydraulic Conductivity al Early Simulation Times 


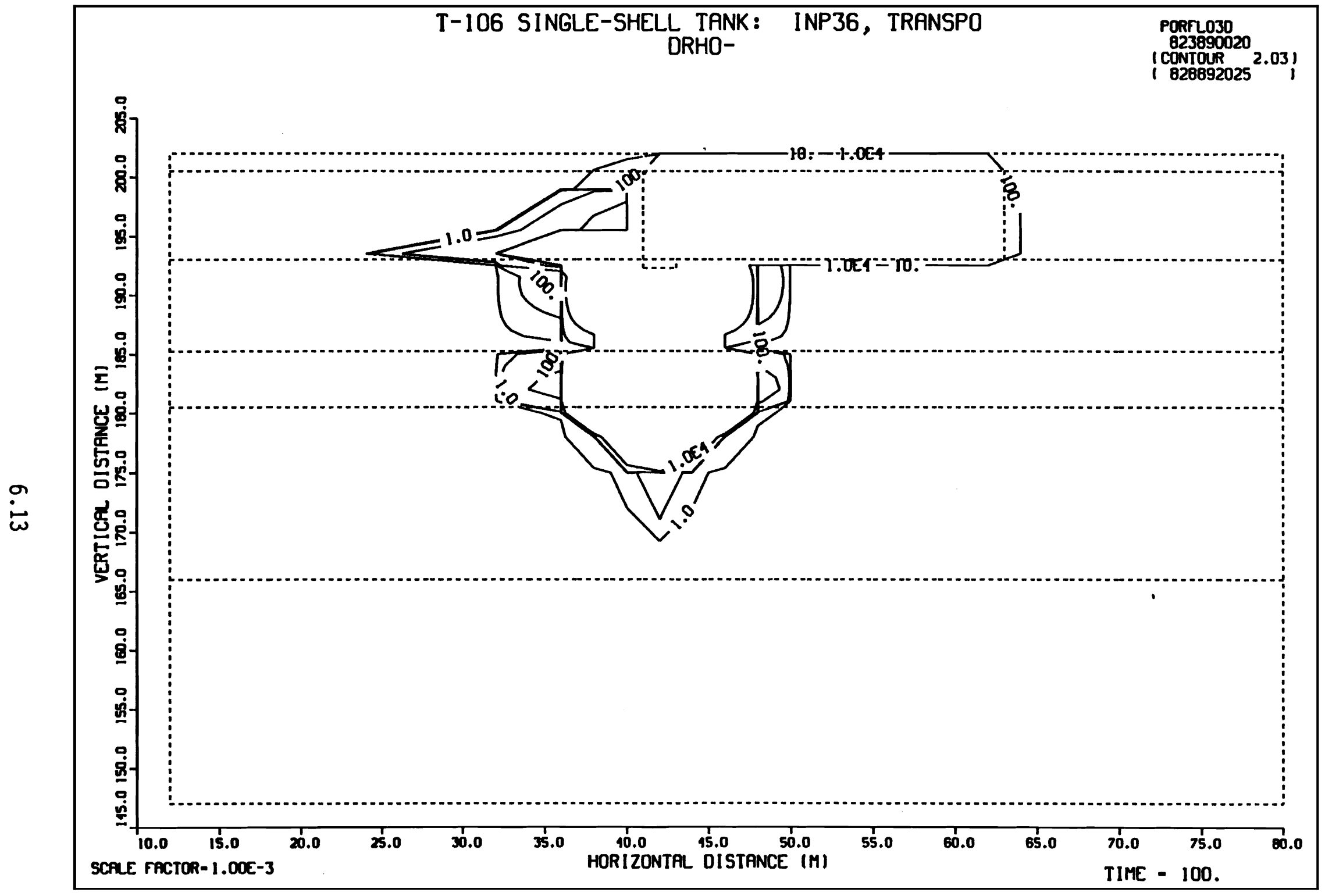

FIGURE 6.10 PORFL0-3 Simulation of the Vertical Extent of the 106Ru After 100 Days With Adjusted Vertical Hydraulic Conductivity 


\section{1-T-106 Tank Leak: Horizontal Profile}

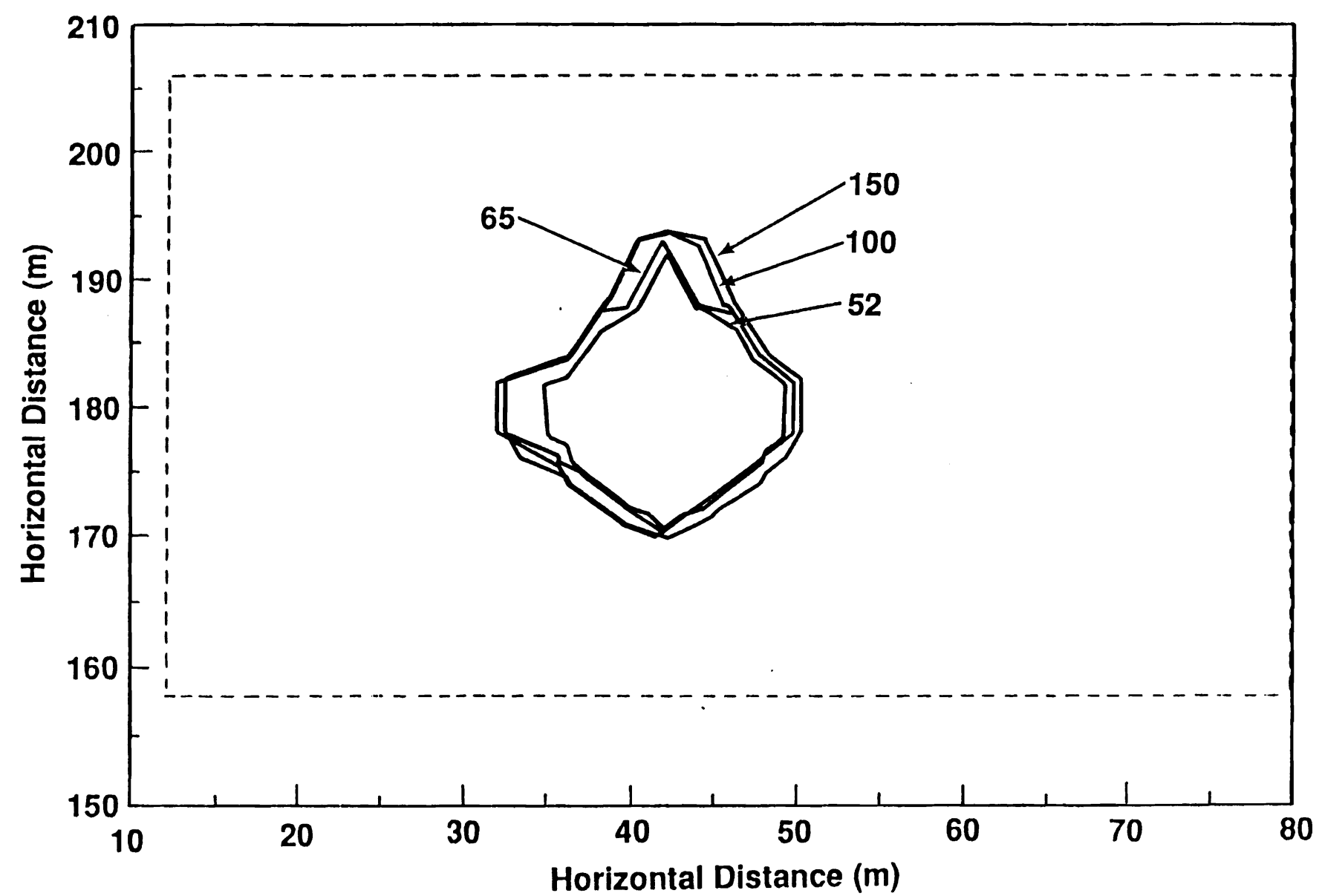

FIGURE 6.11. PORFLO-3 Simulation of the Hotizontal Extent of the 106Ru 1- $\mu$ Ci/L Isopleth With Adjusted Vertical Hydraulic Conductivi?y ot Early Simwletion Times 


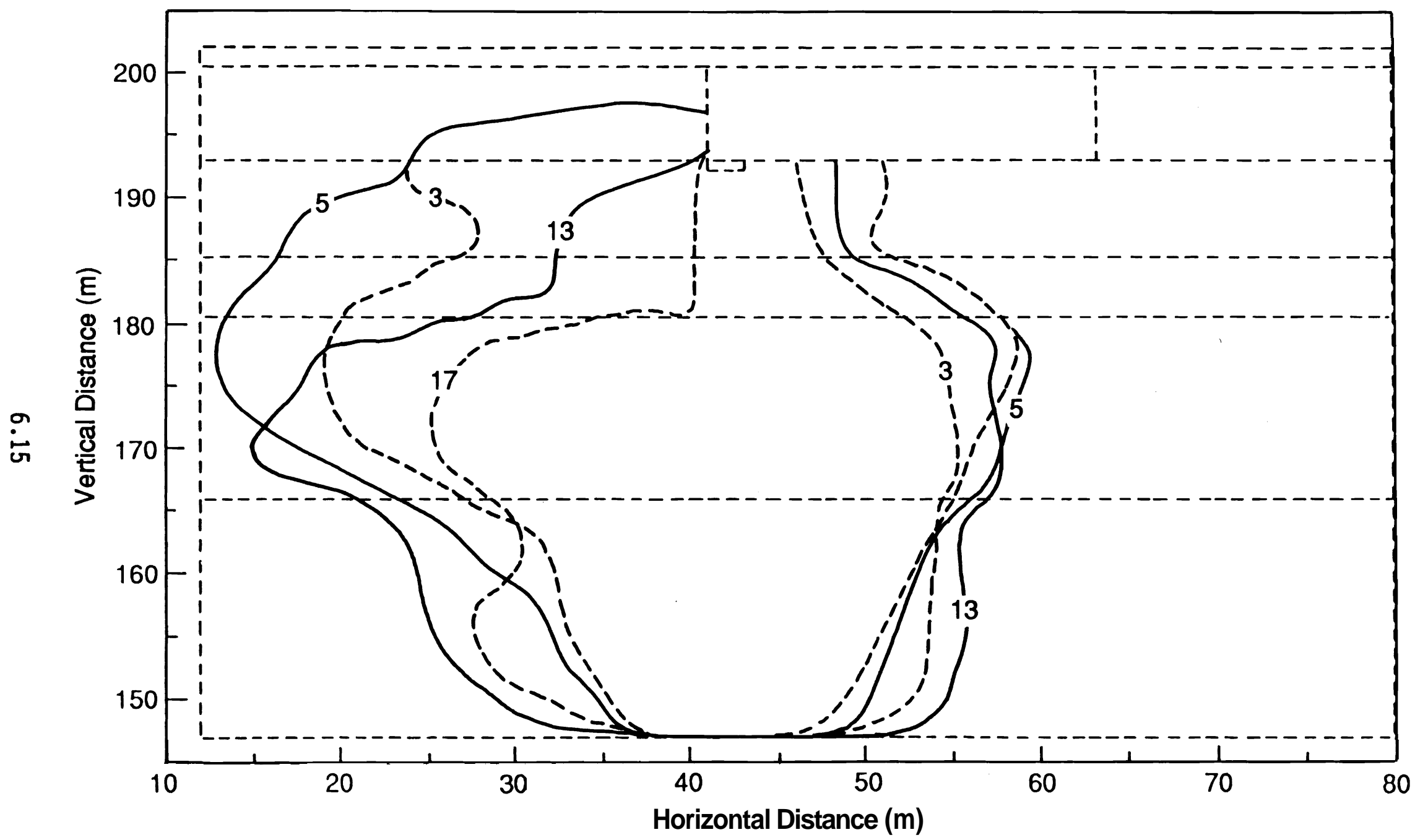

FIGURE 6.12. PORFLO-3 Simulation of the Vertical Extent of the 106Ru 1- $\mu$ Ci/L Isopleth With Adjusted Vertical Hydraulic Conductivity at Late Simulation Times 


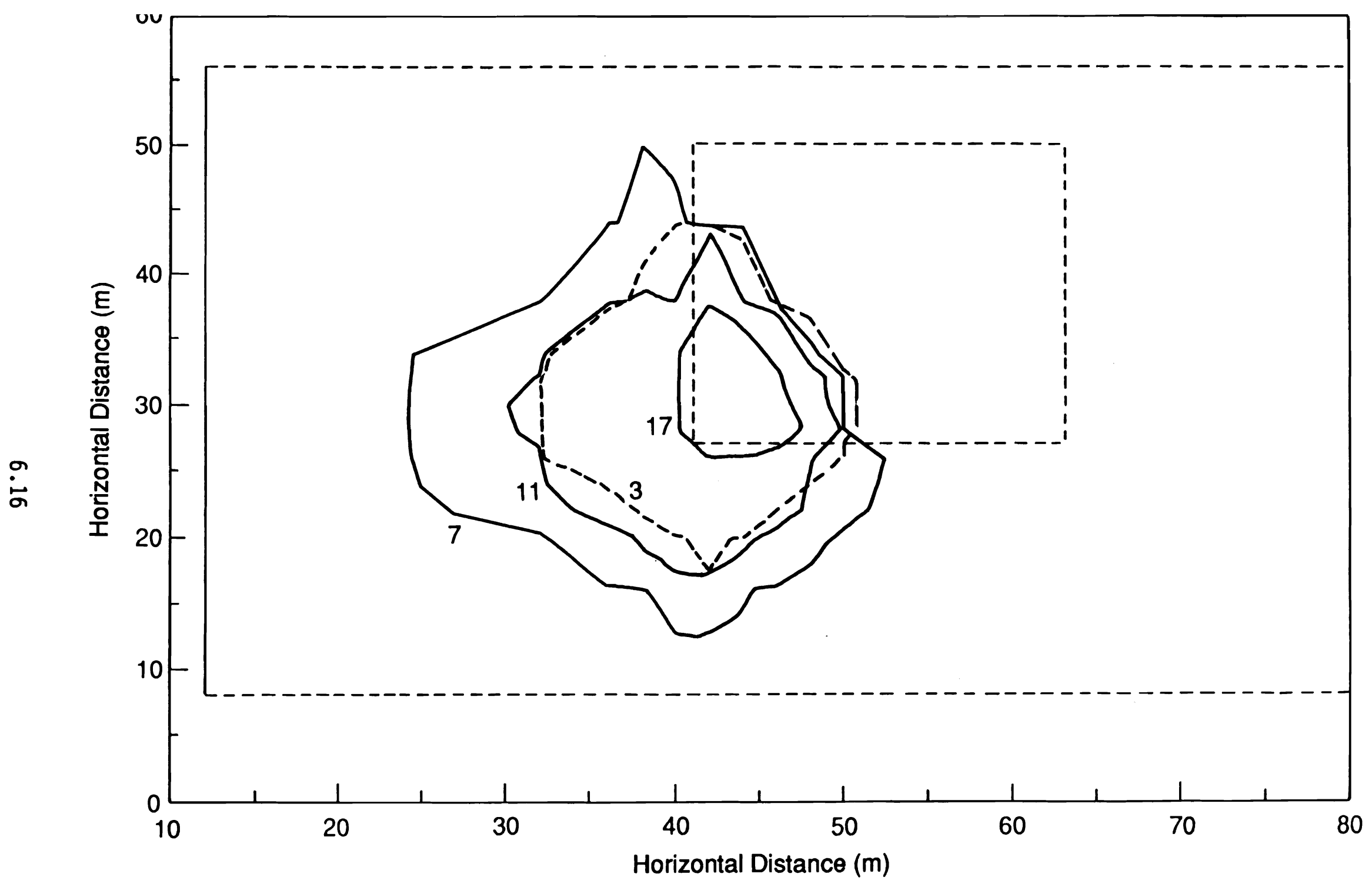

FIGURE 6.13. PORFLO-3 Simulation of the Horizontal Extent of 106Ru 1- $\mu \mathrm{Ci} / \mathrm{L}$ Isopleth with Adjusted Vertical Hydraulic Conductivity at Late Simulation Times 
ruthenium. Radioactive decay of 106Ru appears to only moderately affect reduction of the simulation plume by 1990 , as defined by the $1-\mu \mathrm{Ci} / \mathrm{L}$ isopleth for 106 Ru.

The degree to which 106Ru is adsorbed by Hanford Site soils is uncertain. Ruthenium-106 tends to act as a cation at a pH of less than about 5 , and as an anion at a pH greater than 5 (Ames and Rai 1978). Because Hanford Site soils tend to be neutral to slightly basic and the supernate waste solution in the T-106 Tank had a pH of about 12, cation exchange is probably not a major factor in sorption of 106Ru. Coles and Ramspott (1982) and Ames and Rai (1978) both report that 106Ru moves approximately with the water through soil columns of varying composition, as was the case in the initial set of simulations. However, work by Murthy et al. (1983) indicated that a retardation factor (less than 5) may be associated with 106Ru. Therefore, a second set of simulations was made incorporating a small retardation factor (partition coefficient of $0.5 \mathrm{~mL} / \mathrm{g}$ ) to account for adsorption of 106Ru. A Kd of $0.5 \mathrm{~mL} / \mathrm{g}$ was used, resulting in retardations ranging from about 2.5 to 4 in response to the different porosities of each stratigraphic unit. All other conditions used in the initial set of simulations were held constant.

The results of this simulation are shown in Figures 6.14 through 6.16 for both vertical and horizontal sections through the plume. At 150 days after the beginning of the leak, the plume is about $25 \mathrm{~m}$ below the base of the tank. The horizontal diameter of the $1-\mu \mathrm{Ci} / \mathrm{L}$ isopleth for $106 \mathrm{Ru}$ is about $10 \mathrm{~m}$ at a depth of about $10 \mathrm{~m}$ below the tank. The vertical extent of the plume is similar to that reported by Routson et al. (1979), but the horizontal extent is somewhat smaller.

The simulation isopleths for times of more than 1 year after the leak differ significantly from the simulations that use the unreduced $\mathrm{K}_{z}$. The latter show the $1-\mu \mathrm{Ci} / \mathrm{L}$ isopleth for $106 \mathrm{Ru}$ migrating through much of the soil column above the water table by the early 1980s, but the plume then appears to recede rapidly with the passage of additional time. One explanation could be that retardation causes the concentration gradient between the centroid of the plume and the $1-\mu \mathrm{Ci} / \mathrm{L}$ isopleth for 106Ru to be 


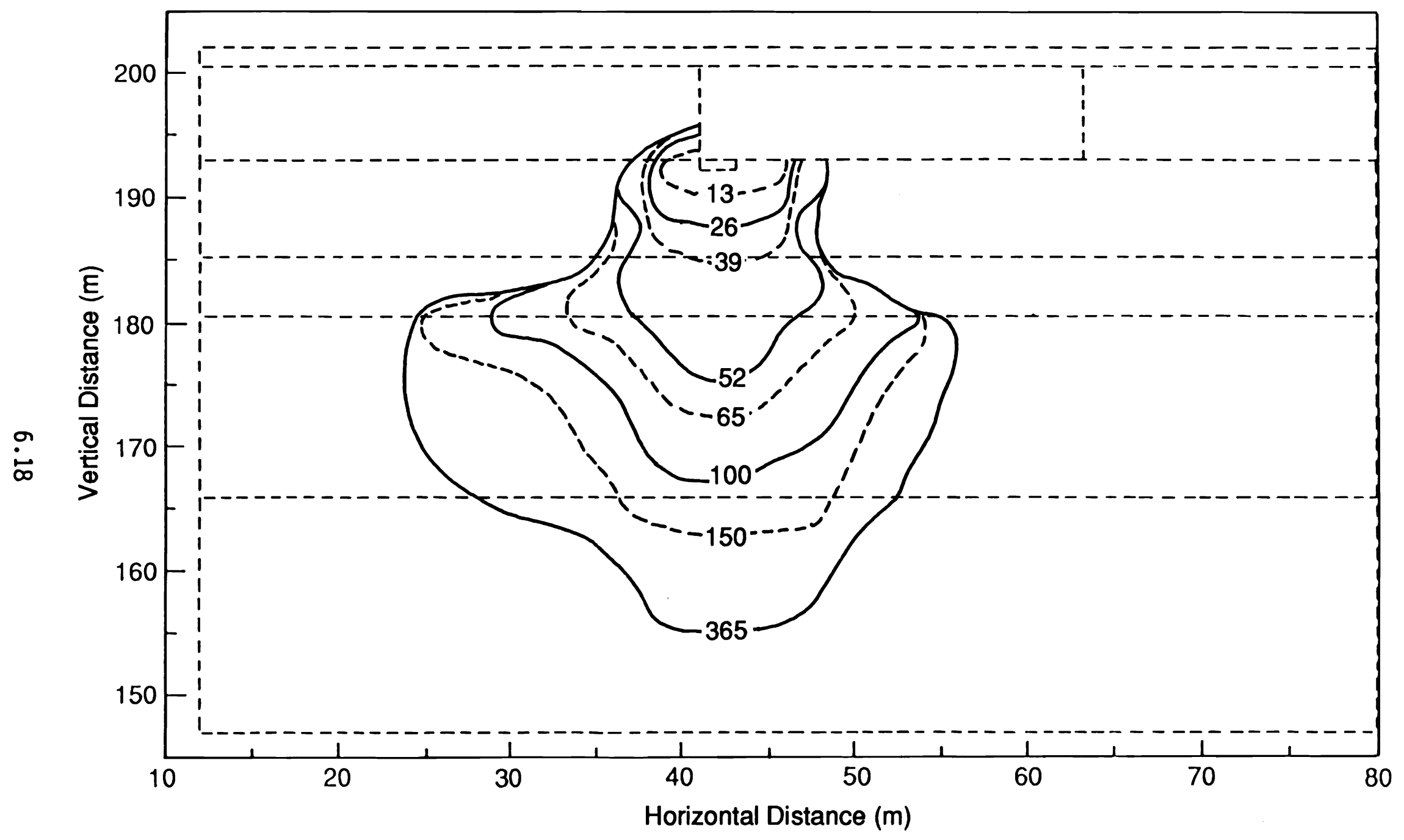

FIGURE 6.14. PORFL0-3 Simulation of the Vertical Extent of the 106Ru 1- $\mu \mathrm{Ci} / \mathrm{L}$ Isopleth for Hydroulically Isotropic Stratigraphic Units With a Distribution Coefóicient of $0.5 \mathrm{~mL} / \mathrm{g}$ at Early Simulation Times 


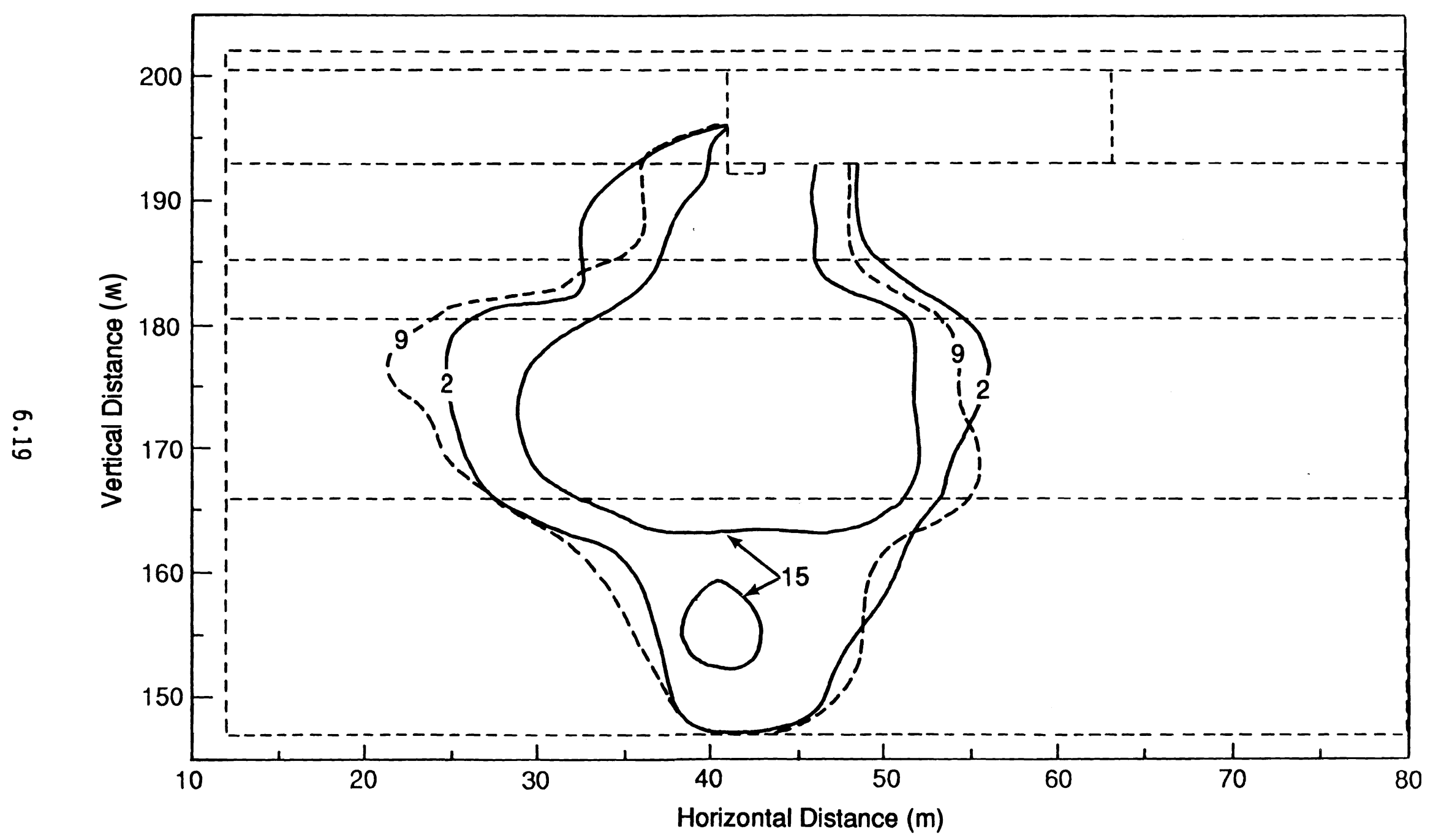

FIGURE 6.15. PORFLO-3 Simulation of the Vertical Extent of the 106Ru 1- $\mu \mathrm{Ci} / \mathrm{L}$ Isopleth for Hydraulically Isotropic Stratigraphic Units With a Distribwtion Coefficient of $0.5 \mathrm{~mL} / \mathrm{g}$ at Late Simulation Times 


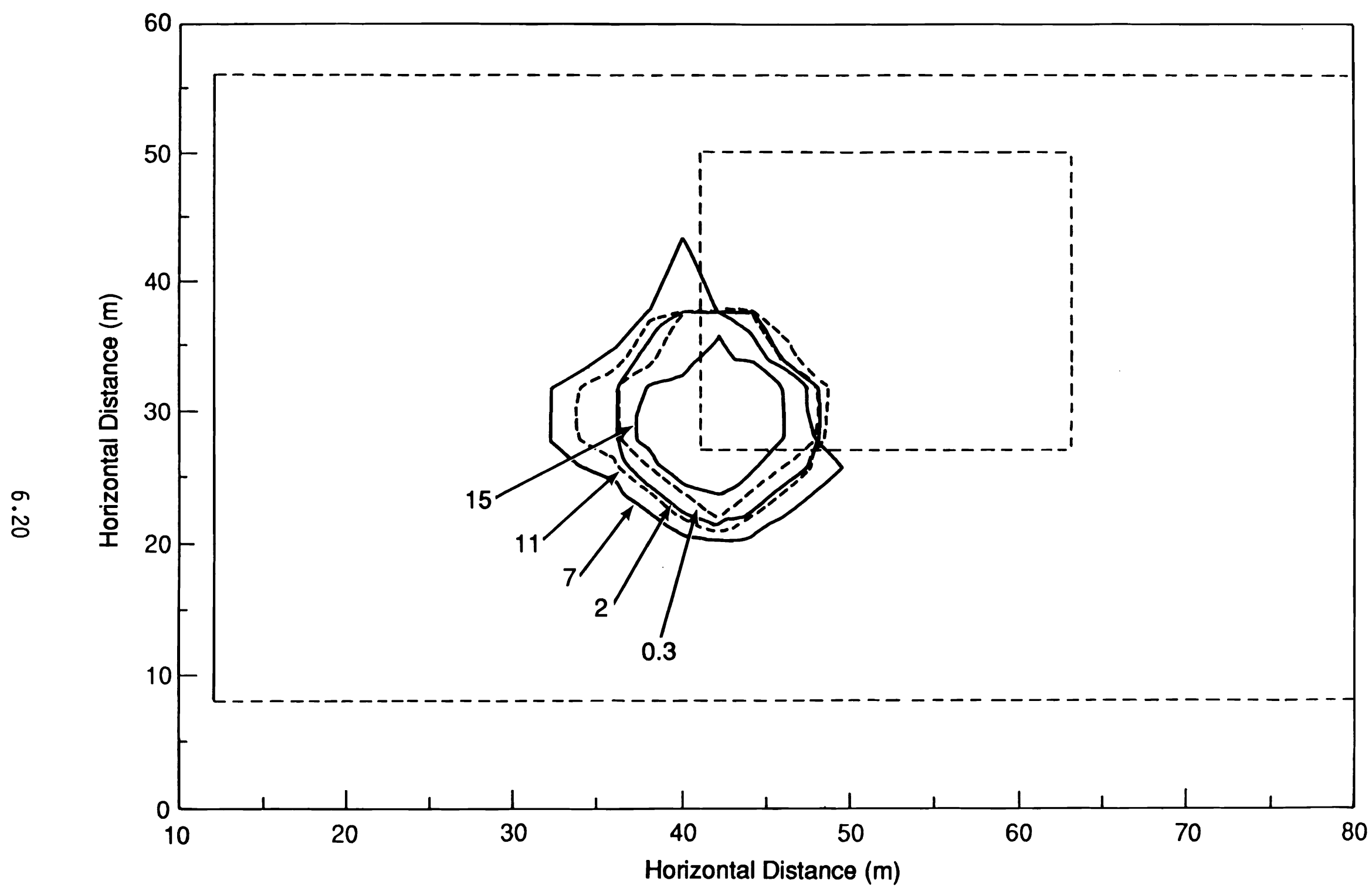

FIGURE 6.16. PORFL0-3 Simulation of the Horizontal Extent of the 106Ru 1- $\mu \mathrm{Ci} / \mathrm{L}$ Isopleth for Hydraulically Isotropic Stratigraphic Units With a Distribution Coefficient of $0.5 \mathrm{~mL} / \mathrm{g}$ 
parabolic, thus resulting in effects of radioactive decay on the $1-\mu \mathrm{Ci} / \mathrm{L}$ isopleth that are larger because of the smaller slope of the concentration gradient near the $1-\mu \mathrm{Ci} / \mathrm{L}$ isopleth.

The plume resulting from the simulation using a retardation coefficient appears to be more compact at early simulation times than the plume resulting from the simulation using a reduced vertical hydraulic conductivity. In other words, the plume that incorporates retardation appears to have a smal ler surface-area-to-volume ratio than that resulting from a reduced $k_{z}$, This result appears reasonable; a reduction in $x_{z}$ would tend to reduce the vertical migration of the plume and force it to spread laterally in the $\mathrm{x}$ and $y$ directions, resulting in a larger surface-area-to-volume ratio in three dimensions. The retardation factor, however, would tend to inhibit movement in all three directions. For a grid cell in the interior of a given stratigraphic unit, the retardation factor should dampen contaminant transport equally in any direction for a unit flux of contaminant. However, there will be small differences in retardation for grid cells located along unit boundaries because of the slightly different retardation coefficients for each stratigraphic unit.

In general, the simulations for 106Ru indicate that the 210-AP tank farm soil properties used to represent the soil column in the vicinity of the 241-T-106 tank are adequate for approximating the plume in three dimensions with relatively little adjustment. It will likely be possible to more closely simulate the actual 106Ru leak with the PORFLO-3 code when sitespecific field data become available.

\subsection{CESIUM-137 PLUME}

A simulation was made for the $137 \mathrm{Cs}$ plume using input parameters equivalent to those used for 106Ru. The same hydraulic properties were used. Cesium-137 has a half-life of about $1.1 \times 10^{4}$ days (30 years) and is much less mobile in Hanford Site soils than 106Ru. For the simulation, a Kd of $1.0 \times 10^{-4} \mathrm{~m} 3 / \mathrm{g}(100.0 \mathrm{~mL} / \mathrm{g})$ was used, resulting in retardations ranging between about 320 and 640 .

Results of the initial simulation for 137 Cs are shown for vertical and horizontal cross sections in Figures 6.17 and 6.18. The $1-\mu \mathrm{Ci} / \mathrm{L}$ isopleth for 137 Cs has migrated to a depth of only several meters below the tank at 


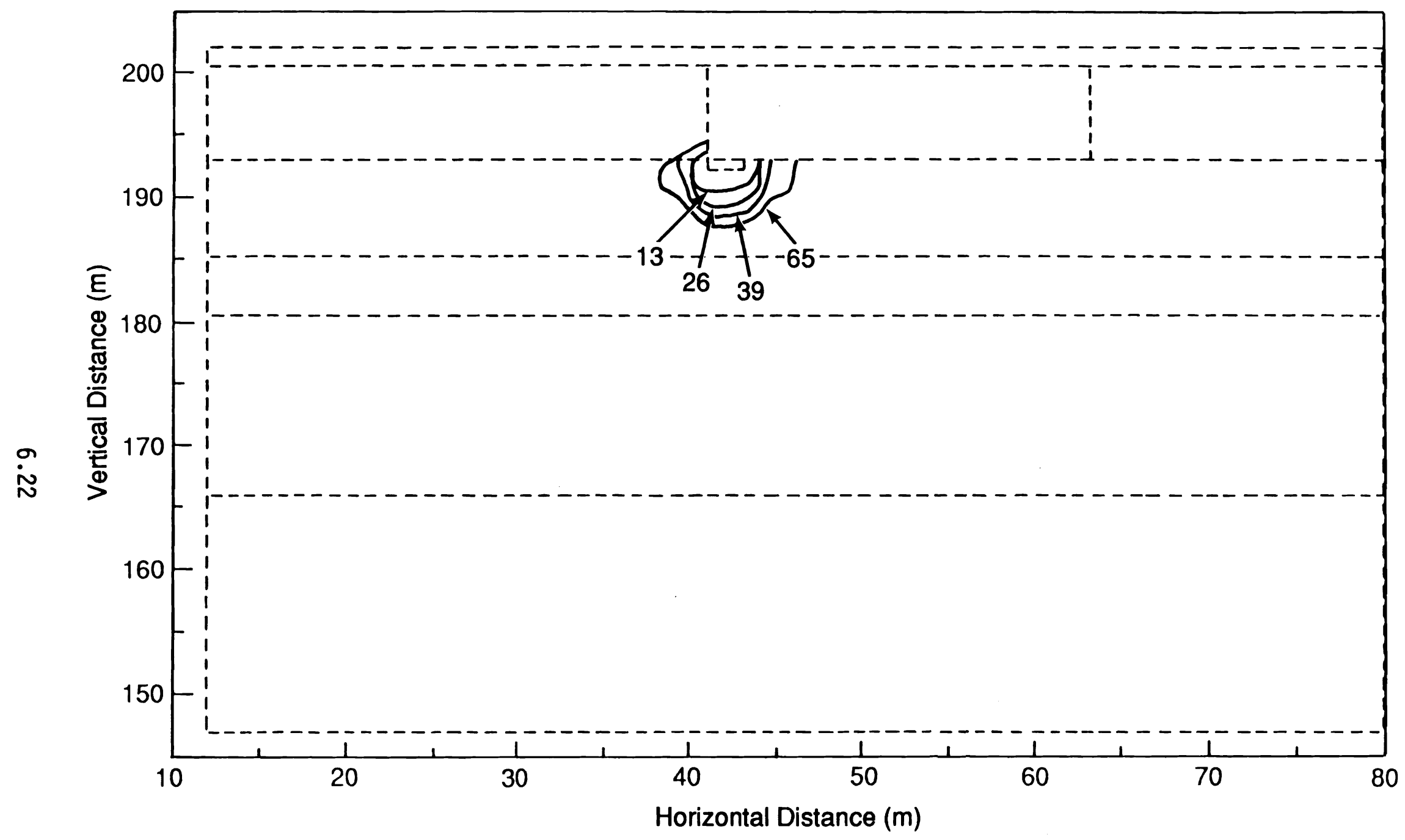

FIGURE 6.17. PORFL0-3 Simulation of the Vertical Extent $\mathrm{O}^{T}$ the $137 \mathrm{Cs} 1-\mu \mathrm{Ci} / \mathrm{L}$ Isopleth Using Data from Field Measurements 


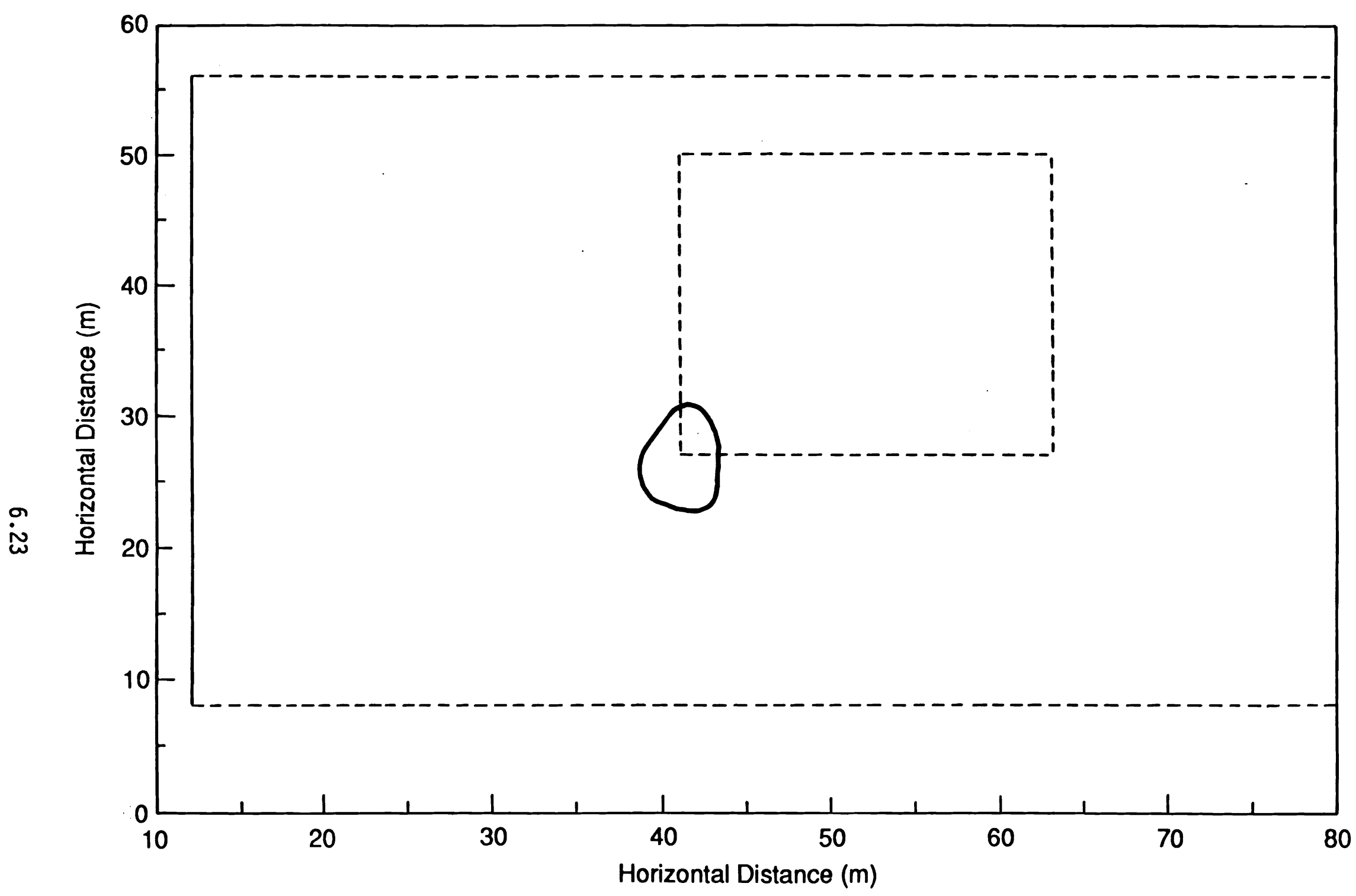

FIGURE 6.18. PORFLO-3 Simulation of the Horizontal Extent of the $137 \mathrm{Cs} 1-\mu \mathrm{Ci} / \mathrm{L}$ Isopleth Using Data from Field Measurements 
150 days after the beginning of the leak. This simulation result compares favorably with observations in the dry wells adjacent to the tank, as reported by Routson et al. (1979). The horizontal plume dimension of 5 to $10 \mathrm{~m}$ also compares favorably with dimensions reported by Routson et al. (1979). Extension of the simulation through 1990 produced very little change in the configuration of the plume relative to its configuration about 65 days after the beginning of the leak. The simulation does not show any redistribution or reduction in the plume with time, probably a result of the high sorption and long half-life of $137 \mathrm{Cs}$. 


\subsection{CONCLUSIONS}

The release of large quantities of fluid and contaminants from the 241-T-106 single-shell waste-storage tank in the 200-West Area of the Hanford Site was analyzed using a three-dimensional numerical model, PORFLO-3 Version 1.0. The analysis was made to calibrate model simulations to field measurements of the contaminant plumes for two radionuclides, ruthenium-106 and cesium-137. The release occurred during a period of 52 days in the summer of 1973. For purposes of the simulation, contaminant release was assumed to occur at a uniform rate during the period of release. The tank itself was assumed to be impermeable, except for a small break at the southwest end of the base where the leak occurred. Soil properties for the simulations were estimated, based on data contained in a catalogue of Hanford Site soil properties.

The model was calibrated to field measurements of the plume from 1973. For $106 \mathrm{Ru}$, the most mobile constituent, a reduction of the saturated hydraulic conductivity used in the initial set of simulations resulted in a plume configuration that closely approximated the measured configuration. Considering that the hydraulic conductivity used initially was for water, but that the leaked liquid was more viscous than water, this reduction in hydraulic conductivity appears reasonable.

Using the calibrated model, the plume measured in 1978 for 106Ru was not approximated by the simulation. The plume measured in 1978 indicated that several meters of migration of the $1-\mu \mathrm{Ci} / \mathrm{L}$ isopleth of $106 \mathrm{Ru}$ occurred in several dry wells after 1973. The simulation, however, indicated a significant spreading of the plume in both the horizontal and the vertical direction since 1973. This result appears to be the consequence of the large amounts of ruthenium that leaked from the tank. Adjustment of the inventory may result in a better simulation approximation of the plume measured in 1978. Additional explanations may include the use of non-site-specific soil properties in the model and real or potential errors in measured data. Measurements of soil properties and the current extent of the plume are needed to resolve these questions. 
The 137 Cs plume was approximated using a reasonable Kd in the simulations. The simulation results indicate that the plume penetrated only several meters below the base of the tank and became essentially stationary within about a month after the tank was pumped out, stopping the leak.

In the absence of information on soil properties specific to the T-106 tank site, Hanford Site soil properties were used. The simulation results approximate the measured $106 \mathrm{Ru}$ and $137 \mathrm{Cs}$ plumes with only minor adjustments of the soil property parameters, while keeping the contaminant source terms fixed. For future assessments, however, the use of soil properties measured at the T-106 tank site is recommended.

Preliminary simulation results indicate that, for the first 150 days, convection was the dominant transport phenomenon and the plume migration was governed by the large volume of the leak, rather than by the rate of infiltration of meteoric water from the surface. At later simulation times, reduction in the extent of the $106 \mathrm{Ru}$ plume by radioactive decay was readily evident.

A saturated hydraulic conductivity on the order of $1 \times 10^{-2} \mathrm{~m} /$ day for the stratigraphic units with relatively low hydraulic conductivities beneath the tank restricts, but does not appear to contain, downward migration of 106Ru.

Several factors were not incorporated into the analysis. The thermal and viscosity effects of the liquid waste and active two-phase flow in the unsaturated zone were not included. The uncertainty introduced by not considering these factors is probably small relative to the lack of sitespecific moisture retention properties. The PORFLO-3 code does not account for hysteresis in the soil-moisture characteristic curves. Hysteresis could have a significant impact on the movement of the liquid waste plume. Measurement of imbibition and drainage properties of at least the major soil horizon beneath the T-106 tank should be incorporated into plans for site characterization. These data may be significant in understanding the fate of plumes in the unsaturated zone, and plans for their collection should provide the impetus for code modifications to incorporate hysteresis. 
Data on contaminant plumes in the vadose zone are rare. Consequently, the 241-T-106 leak data provided a rare opportunity to test the capabilities of the PORFLO-3 computer code. The PORFLO-3 code used for this analysis incorporates a complex set of equations for water flow, heat transfer, and mass transport. Its application to the 241-T-106 leak data, as discussed in this report, suggests that the code would be useful in helping to delineate and predict potential future movement of contaminant plumes from other sources at the Hanford Site, such as cribs and trenches. 



\subsection{REFERENCES}

Ames, L. L., and D. Rai. 1978. Radionuclide Interactions With Soil and Rock Media, Volume 1. EPA 520/6-78-007, Environmental Protection Agency, Washington, D.C.

Atlantic-Richfield Hanford Company (ARHCO) . 1973. 241-T-106 Tank Leak Investigation. ARH-2874, Atlantic Richfield Hanford Company, Richland, Washington.

Atomic Energy Commission (AEC-RL). 1973. Report on the Investigation of the 106-T Tank Leak at the Hanford Reservation, Richland, Washington. TID 26431, AEC-RL, Richland, Washington.

Bjornstad, B. N. 1983. Suprabasalt Stratigraphy Within and Adjacent to the Reference Repository Location. SD-BWI-DP-039, Rockwell Hanford Operations, Richland, Washington.

Coles, D. G., and L. D. Ramspott. 1982. "Migration of Ruthenium-106 in a Nevada Test Site Aquifer: Discrepancy Between Field and Laboratory Results." Science 215:1235-1236.

Evans, J. C., D. I. Dennison, R. W. Bryce, P. J. Mitchell, D. R. Sherwood, K. M. Krupka, N. W. Hinman, E. A. Jacobson, and M. D. Freshley. 1988. Hanford Site Ground-Water Monitoring for July Through December 1987.

PNL-6315-2, Pacific Northwest Laboratory, Richland, Washington.

Fecht, K. R., and W. H. Price. 1977. Granulometric Data 241-T Tank Farm Monitoring Well Sediments. RHO-LD-19, Rockwell Hanford Operations, Richland, Washington.

Gee, G. W. 1987. Recharge at the Hanford Site: Status Report. PNL-6403, Pacific Northwest Laboratory, Richland, Washington.

Gillette, R. 1973. "Radiation Spill at Hanford: The Anatomy of an Accident." Science 181:728-730.

Isaacson, R. E. 1982. Supporting Information for the Scientific Basis for Establishing Dry Well Monitoring Frequencies. RHO-RE-EV-4 P, Rockwell Hanford Operations, Richland, Washington.

Jensen, E. J., S. P. Airhart, M. A. Chamness, T. J. Gilmore, D. R. Newcomer, and K. R. Oster. 1989. 40 CFR 265 Interim-Status Ground-Water Monitoring Plan for the Single-Shell Tanks. WHC-SD-EN-AP-012, Westinghouse Hanford Company, Richland, Washington.

Last, G. V., and B. N. Bjornstad. 1989. Revised Ground-Water Monitoring Plan for the 200 Areas Low-Level Burial Grounds. PNL-6902, Pacific Northwest Laboratory, Richland, Washington. 
Last, G. V., B. N. Bjornstad, M. P. Bergeron, D. W. Wallace, D. R. Newcomer, J. A. Schramke, M. A. Chamness, C. S. Cline, S. P. Airhart, and J. S. Wilbur. 1989. Hydrogeology of the 200 Areas Low-Level Burial Grounds - An Interim Report. PNL-6820, Vol. 1, Pacific Northwest Laboratory, Richland, Washington.

Murthy, K. S., L. A. Stout, B. A. Napier, A. E. Reisenauer, and D. K. Landstrom. 1983. Assessment of Single-Shell Tank Residual Liquid Issues at Hanford Site, Washington. PNL-4688, Pacific Northwest Laboratory, Richland, Washington.

Philip, J. R., J. H. Knight, and R. T. Waechter. 1989. "Unsaturated Seepage and Subterranean Holes: Conspectus, and Exclusion Problem for Circular Cylindrical Cavities." Water Resources Research 25(1):16-28.

Price, W. H., and K. R. Fecht. 1976. Geology of the 241-T Tank Farm. ARH-LD-135, Atlantic Richfield Hanford Company, Richland, Washington.

Routson, R. C., W. H. Price, D. J. Brown, and K. R. Fecht. 1979. HighLevel Waste Leakage from the 241-T-106 Tank at Hanford. RHO-ST-14, Rockwe 1 Hanford Operations, Richland, Washington.

Runchal, A. K., and B. Sagar. 1989. PORFL0-3: A Mathematical Model for Fluid Flow, Heat, and Mass Transport in Variably Saturated Geologic Media, Users Manual, Version 1.0. WHC-EP-0041, Westinghouse Hanford Company, Richland, Washington.

Sagar, B., and A. K. Runchal. 1989. PORFLO-3: A Model for Fluid Flow, Heat, and Mass Transport in Variably Saturated Fractured or Porous Media Theory Manual. WHC-EP-0042, Westinghouse Hanford Company, Richland, Washington.

Sewart, G. H., W. T. Farris, D. G. Huizenga, A. H. McMakin, G. P. Streile, and R. L. Treat. 1987. Long-Term Performance Assessment of Grouted Phosphate/Sulfate Waste From N Reactor Operations. PNL-6152, Pacific Northwest Laboratory, Richland, Washington.

Tallman, A. M., K. R. Fecht, M. C. Marratt, and G. V. Last. 1979. Geology of the Separation Areas, Hanford Site, South-Central Washington. RHD-ST-23, Rockwell Hanford Operations, Richland, Washington.

Thurman, J. M. 1989. Tank Farm Surveillance and Waste Status Summary Report for December 1988. WHC-EP-0182-9, Westinghouse Hanford Company, Richland, Washington.

U.S. Department of Energy (DOE). 1987. Final Environmental Impact Statement, Disposal of Hanford Defense High-Level, Transuranic and Tank Wastes. DOE/EIS-0113, Vols. 1-5, U.S. Department of Energy, Washington, D.C. 
U.S. Energy Research and Development Administration (ERDA). 1975. Final Environmental Statement, Waste Management Operations, Hanford Reservation. Two vols. ERDA-1538, National Technical Information Service, Springfield, Virginia. 



\section{DISTRIBUTION}

No. of

Copies

\section{OFFSITE}

12 DOE/Office of Scientific and Technical Information

2 DOE Office of Civilian Radioactive Waste Management Forrestal Building Washington, DC 20585

ATTN: S. Rousso, RW-10

R. Stein, RW-30

2 DOE Office of Defense Waste \& GTN Transportation Management

Washington, DC 20545

ATTN: K. A. Chacey, DP-123

T. B. Hindman, DP-12

4 DOE Office of Remedial Action GTN

\& Waste Technology

Washington, DC 20545

ATTN: J. E. Baublitz, NE-20

J. A. Coleman, NE-24

T. W. McIntosh, NE-24

H. F. Walter, NE-24

3 DOE Idaho Operations Office

550 Second Street

Idaho Falls, ID 83401

ATTN: C. R. Enos

M. W. Shupe

J. E. Solecki

C. S. Abrams

Argonne National Laboratory

P.0. Box 2528

Idaho Falls, ID 83401

R. G. Baca

$E G \& G$, Inc.

2151 North Blvd.

Idaho Falls, ID 83415
No. of

Copies
J. W. Bartlett

The Analytic Sciences Corporation 55 Walkers Brook Drive

Reading, MA 01867

3 Battelle Memorial Institute

Project Management Division

505 King Avenue

Columbus, OH 43201

ATTN: W. A. Carbeiner

R. A. Nathan

Technical Library

J. R. Berreth

Westinghouse Idaho

Nuclear Co., Inc.

P.0. Box 4000

Idaho Falls, ID 83401

W. Brewer

Office of High-Level Nuclear Waste Management

Washington State Department of Ecology

Mail Stop PV-11

Olympia, WA 98504

W. J. Brumley

DOE Savannah River Operations Office

P.0. Box A

Aiken, SC 29801

G. S. Campbe 11

Agronomy Department Washington State University Pullman, WA 99164

A. T. Clark

Division of Fuel Material Safety

Nuclear Regulatory Commission

Washington, DC 20555 
No. of

Copies

G. A. Dinwiddie

U.S. Geological Survey

12201 Sunrise Valley Drive

Reston, VA 22092

6 E. I. du Pont de Nemours Company

Savannah River Laboratory

Aiken, SC 29801

ATTN: R. G. Baxter

M. D. Boersma

J. G. Glasscock

J. R. Knight

M. J. Plodinec

C. T. Randall

J. Fischer

Low-Level Radioactive Waste Program

U.S. Geological Survey

Water Resources Division

12201 Sunrise Valley Drive

Reston, VA 22092

F. T. Fong

DOE San Francisco Operations

1333 Broadway

Oakland, CA 94612

W. T. Goldston

DOE Savannah River Operations Office

P.0. Box A

Aiken, SC 29801

T. E. Hakonson

Los Alamos National Laboratory

P.0. Box 1663

Los Alamos, NM 87545

D. Hillel

Department of Plant and Soil Science

12A Stockbridge Hall

University of Massachusetts

Amherst, MA 01003
No. of

Copies

Dwight Hoxie

U.S. Geological Survey

P.0. Box 25046, MS 421

Lakewood, CO 80225

E. A. Jacobson

Desert Research Institute

P.0. Box 60220

Reno, NV 89506

E. A. Jennrich

EG\&G Idaho

P.0. Box 1625

Idaho Falls, ID 83415

M. R. Jugan

DOE Oak Ridge Operations Office

P.0. Box E

Oak Ridge, TN 37830

W. A. Jury

Department of Soils

University of California

at Riverside

Riverside, CA 92502

D. A. Knecht

Westinghouse Idaho Nuclear

Company

P.0. Box 4000

Idaho Falls, ID 83403

D. Langmuir

Department of Chemistry and Geochemistry

Colorado School of Mines

Golden, CO 80401

E. Maestas

DOE West Valley Project Office

P.0. Box 191

West Valley, NY 14171

S. 0. Magnuson

$E G \& G$, Inc.

2151 North Blvd.

Idaho Falls, ID 83415 
No. of

Copies

J. M. McGough

DOE Albuquerque Operations

Office

P.0. Box 5400

Albuquerque, NM 87115

Sheldon Meyers

Environmental Protection Agency

Office of Radiation Programs (ANR-458)

401 M Street S.W.

Washington, DC 20460

S. P. Neuman

Professor of Hydrology

Department of Water Resources

Building 11

University of Arizona

Tucson, AZ 87521

T. J. Nicholson

U.S. Nuclear Regulatory

Commission

Div of Engineering Safety

MS NL-005

Washington, DC 20555

J. W. Nyhan

Los Alamos National Laboratory

P.0. Box 1663

Los Alamos, NM 87545

4 Oak Ridge National Loaboratory

P.0. Box $Y$

Oak Ridge, TN 37830

ATTN: W. D. Burch

R. T. Jubin

L. J. Mezga

D. W. Turner

D. T. Oakley, MS-J521

Los Alamos Scientific Laboratory

P.0. Box 1663

Los Alamos, NM 87544

E. O'Donnell

Nuclear Regulatory Commission

MS-NLS-260

Washington, DC 20555
No. of

Copies

U-Sun Park

SAIC

101 Convention Center Drive, Suite 860

Las Vegas, NV 89109

K. Pruess

Earth Sciences Division

Lawrence Berkeley Laboratory

University of California

Berkeley, CA 94720

L. D. Ramspott

Lawrence Livermore National Laboratory

University of California

P.0. Box 808

Livermore, CA 94550

J. Rensel

High-Level Waste Management

Washington State Department of Ecology

Mail Stop Pu II

Olympia, WA 98504

A. D. Rodgers

Mail Stop 2411

EG\&G Idaho

P.0. Box 1625

Idaho Falls, ID 83415

2 Sandia Laboratories

P.0. Box 5800

Albuquerque, NM 87185

ATTN: R. W. Lynch

Technical Library

P. A. Saxman

DOE Albuquerque Operations Office

P.0. Box 5400

Albuquerque, NM 87185

R. R. Seitz

$E G \& G$, Inc.

2151 North Blvd.

Idaho Falls, ID 83415 
No. of

Copies

R. Shaw

Electric Power Research Institute

3412 Hillview Avenue

P.0. Box 10412

Palo Alto, CA 94304

M. J. Steindler

Argonne National Laboratory

9700 South Cass Avenue

Argonne, IL 60439

V. Stello

office of the Executive

Director for Operations

Mail Station 17-G21

Nuclear Regulatory Commission

Washington, DC 20555

D. B. Stephens

Daniel B. Stephens \& Associates

4415 Hawkins NE

Albuquerque, NM 87109

C. F. Tsang

Earth Sciences Division

Lawrence Berkeley Laboratory

University of California

Berkeley, CA 94720

S. Tyler

Desert Research Institute

P.0. Box 60220

Reno, NV 89506

J. S. Wang

Earth Sciences Division

Lawrence Berkeley Laboratory

University of California

Berkeley, CA 94720

E. P. Weeks

U.S. Geological Survey

Federal Center Mail Stop 413

Denver, C0 80225
No. of

Copies

5 Westinghouse Savannah River

Company

Savannah River Site

Aiken, SC 29801

ATTN: R. G. Baxter

M. D. Boersma 77341A

J. R. Knight $773 \mathrm{~A}$

M. J. Plodinec $773 \mathrm{~A}$

C. T. Randall 7042

4 West Valley Nuclear Services Company

P.0. Box 191

West Valley, NY 14171

ATTN: R. R. Borisch

J. Buggy

J. M. Pope

R. A. Thomas

J. L. White, Chairman

Energy Research \& Development Authority

Empire State Plaza

Albany, NY 12223

P. J. Wierenga

Department of Soil and Water Science

University of Arizona

Tucson, AZ 85721

I. J. Winograd

U.S. Geological Survey

National center - Mail Stop 432

Reston, VA 22092 
No. of

Copies

ONSITE

12 DOE Richland Operations Office

G. J. Bracken

J. J. Broderick

C. E. Collantes

C. R. DeLannoy

J. R. Hunter

A. J. Knepp

O. L. Olson

J. M. Peterson

G. W. Rosenwald

M. W. Shupe

J. J. Sutey

D. M. Wanek

25 Westinghouse Hanford Company

M. R. Adams

L. C. Brown

J. W. Cammann

M. P. Connolley

H. F. Daugherty

J. D. Davis

K. R. Fecht

V. W. Hall

C. H. Huang

R. L. Jackson

M. T. Jansky

K. N. Jordan

R. Khaleel

D. S. Landeen

R. E. Lerch

H. E. McGuire

S. J. Phillips

W. A. Price

R. E. Raymond

J. F. Relyea

J. C. Sonnichsen

N. R. Wing

D. D. Wodrich

R. D. Wojtasek

J. C. Womack
No. of

$\underline{\text { Copies }}$

57 Pacific Northwest Laboratory

N. J. Aimo

P. A. Beedlow

M. P. Bergeron

L. L. Cadwell

M. D. Campbe 11

J. W. Cary

C. R. Cole

P. G. Doctor

J. L. Downs

J. W. Falco

M. J. Fayer (2)

M. G. Foley

M. D. Freshley

G. W. Gee

M. J. Graham

K. R. Hanson

P. C. Hays

D. J. Holford

T. L. Jones

C. T. Kincaid

R. R. Kirkham

G. V. Last

S. 0. Link

J. F. McBride

E. M. Murphy

R. W. Nelson

M. L. Rockhold

B. Sagar (5)

C. S. Simmons

R. L. Skaggs

J. L. Smoot (10)

J. D. Smyth

J. A. Stottlemyre

G. P. Streile

C. F. Voss

W. J. Waugh

J. Weber

R. E. Wildung

Publishing Coordination

Technical Report Files (5) 